\title{
1 Textual traditions
}

Introductory remarks by the chapter editor, Elisabet Göransson

Textual criticism and the study of the transmission of texts is by and large dependent on writing and written sources. The development of literacy, from the oral transmission of texts to the development of written records, was a long process indeed, and it took place in various parts of the world. The earliest stages of writing were pictograms, used by the Sumerians, Egyptians, and Chinese, from which ideographic or logographic writing, which expressed abstractions, was developed. Phonetic writing, in which symbols, phonograms, represent sounds rather than concepts, was then developed into syllabic and later into alphabetic writing. Early Sumerian literature and Egyptian literature, both extant from the late fourth millennium BC onwards, constitute the oldest literatures we know of. A wide range of literary texts letters, hymns, and poems, but also autobiographical texts - were written in Egyptian hieroglyphs. A narrative Egyptian literature became common from the twentyfirst century BC onwards (during the Middle Kingdom). The cursive shorthand known as the hieratic script gradually became more widely used, both for recordkeeping and for correspondence. Later on, the demotic script was developed from the late Egyptian hieratic script for the same day-to-day uses, and finally the Egyptians settled on a revised form of the Greek alphabet, the Coptic alphabet, which simplified writing most decidedly. Similarly, cuneiform literature from the ancient Near East, preserved on mostly fragmentary clay tablets, consists of a large corpus of narrative and laudatory poetry, hymns, laments and prayers, fables, didactic and debate poems, proverbs, and songs (T. L. Holm 2005).

Even though writing and literature thus existed for a long time before classical Antiquity, for the study of textual criticism and stemmatology - i.e. the relations between the textual witnesses of a textual tradition - approaches to studying the transmission of Greek and Latin texts have been the main points of departure. The basic concepts, methodology, and terminology used by scholars within the field of stemmatology draw exclusively on the literary development and the copying of texts in ancient Greek and Latin. Hence, the perspective in this book and in this introductory chapter is based on the background of the ancient Graeco-Roman world. An overview of other types of literary cultures, specific textual traditions, and editorial approaches used for manuscript traditions in other parts of the world can be found in chapter 7 of the present book (on early Ethiopian, Hebrew, and Chinese literary cultures). For more case studies of oriental manuscript traditions, the reader is referred to the Comparative Oriental Manuscript Studies handbook (Bausi et al. 2015, 363-462).

The textual traditions and transmission of the literary texts we study and analyse depend on many different circumstances. The nature of the preserved manuscripts, their material transmission, authorship, genre, the complexity of the textual tradition, and so on constitute specific challenges for the editor when deciding upon 
the method(s) to use for analysis and the form of presentation of the text. These circumstances all define the specific editorial situation in a process that can be described as more hermeneutic than strictly linear, so there is no simple recipe applicable to all cases (Göransson 2016, 401). What types of structural and textual variation are there in a specific textual tradition? Sometimes, it is possible to trace the development of a text that underwent changes; in other cases, the evidence may be lacking. Sometimes, the differences in the tradition can be described without the intention of tracing the actual origin of the textual tradition. It all depends on the unique editorial situation, on how the texts have been transmitted, what evidence of the transmission we can find. Still, there are general rules and tools, applicable to these many varying cases, with which the present book is concerned. In this introductory chapter, different perspectives on transmitted texts witnessed primarily in manuscripts, but also in early prints, will be presented to give a historical and methodological perspective on the field.

Gerd Haverling starts by providing an introduction to aspects of literacy and the development of literature in ancient Greek and Latin in section 1.1. Sinéad O'Sullivan, in section 1.2, explains the basic terms used when discussing the transmission of texts, the media transmitting them, and the copying of them. Next, book production and libraries from Graeco-Roman Antiquity onwards, including the paradigm shifts from written to printed books, as well as from printed to digital, are presented in section 1.3, by Outi Merisalo. The ancient libraries of handwritten books, private and public, were replaced by other types of libraries as a result of the renaissance of book production in Carolingian times (ninth century) as well as in the late Middle Ages and the early modern period. Merisalo also gives a broad introduction to the history of our modern-period libraries and their collections, while closing with some perspectives on the digital turn and on the effects of current digitisation processes in libraries and other institutions holding historical heritage.

After this historical background and introduction to the basic terminology used, Iolanda Ventura and Peter Stokes provide a context for the study of stemmatology from two different perspectives. In section 1.4, Iolanda Ventura discusses earlier textual scholarship with specific reference to the role of philological practices when literature was first presented in print. The reception of older texts as witnessed in early prints has often been neglected in modern critical editions, despite the fact that the prints not only witness the reception of those texts but are sometimes apographs of lost manuscript witnesses. The humanists, who were the first to make classical, patristic, and mediaeval literature available in print, had various approaches: their editions are not a homogeneous group, for the early prints were established on quite different principles that are far from transparent since they were often not described at all. Nevertheless, this reception also deserves to be studied: early prints sometimes contribute to the establishment of a critical text. Examples are given both for classical and patristic texts.

Palaeography and codicology, which study the material forms that texts have been transmitted in, are vital for stemmatology. They illuminate other aspects of the 
transmission and reception of the texts, and inform the discussion of the relevant methods to use when editing them. In section 1.5, Peter Stokes addresses this by giving some definitions and a historical introduction to the development of palaeography and codicology; moreover, he illustrates with examples how editing is intimately intertwined with a deep understanding of palaeography and codicology. Finally, the question of collaboration and multidisciplinarity/interdisciplinarity as a prerequisite for successful scholarship in the field of stemmatology in the digital age is raised and discussed.

\title{
1.1 Literacy and literature since Antiquity
}

\author{
Gerd V. M. Haverling
}

Literacy was no doubt a very rare thing following its introduction, and it was not always used for literature. However, from the classical period in Greece (ca. 480$323 \mathrm{BC}$ ) onwards, we witness a growing importance of writing and books. In the Roman world, literacy seems to have been more common than during the first centuries of the Middle Ages; only in the later Middle Ages did the use of writing and books increase again.

\subsubsection{Orality and literacy in Antiquity}

The earliest texts in Greek date from the latter part of the second millennium BC. The Mycenaean civilisation flourished on mainland Greece and the surrounding islands ca. 1600-1100 BC. Its syllabic script (linear B) was used for administrative purposes and not for literature; with the end of the Mycenaean culture in the twelfth century BC, it was lost. Around 800 BC, the Greeks adopted the Phoenician writing system and created their alphabet, for the first time including vowels. The new Greek script arrived in Italy as early as the first part of the eighth century BC, when the various peoples on the peninsula started to use it for their own languages. The Romans obtained it from the Etruscans; both the earliest known Etruscan and Latin inscriptions date from the seventh century BC (see e.g. Harris 1989, vii, 45, 149; Mallory and Adams 2006, 27-28; M. Weiss 2009, 23-30).

Before literacy became an important factor, there was a tradition of transmitting long stretches of texts orally. The Vedic texts, the oldest part of Sanskrit literature, were transmitted orally for centuries before they were finally written down (see e.g. Mallory and Adams 2006, 33). There are traces of similar traditions among the ancient Greeks and Romans, too.

The extent of the use of writing for literary works among the Greeks in the archaic period (eighth century to ca. 480 BC) is a much-discussed topic. Before they 
were written down, the Homeric poems were recited orally from memory by specially trained rhapsodes. The Iliad and the Odyssey contain formulae, stock epithets, and phrases which reflect such oral habits: it therefore seems likely that the poems were not the work of one individual but the product of a "long series of compositions and re-compositions" (Graziosi 2002, 15). Some scholars have followed the traditional account, according to which the Homeric poems were first written down in the middle of the sixth century in Athens during the reign of Pisistratus (thus e.g. Skafte Jensen 1980, 9-10, 128; cf. also e.g. Hinge 2006, 304-306). Others believe, however, that the poets who first wrote down the Homeric poems lived earlier and that Hesiod, the first Greek poet known to us as an individual, already used writing when he composed his poems around 700 BC (thus e.g. West 1978, 41-59; cf. also Reynolds and Wilson 2013, 1; Pöhlmann 1994, 11-12). The first literary works were thus poetry, but from the sixth century we hear of works composed in prose on history and philosophy. In the classical period (ca. 480-ca. 323 BC), a growing number of genres in prose as well as poetry are cultivated (see e.g. Lesky 1996, 216-223, 241-641; see also Pöhlmann 1994).

There are also some traces of a pre-literary form of poetry among the Romans: religious songs such as the Carmen Saliare and the Carmen Arvale seem to have such a background, and had become virtually incomprehensible to Romans in the later Roman Empire (see e.g. Poccetti and Santini 1999, 204-208; Clackson and Horrocks 2007, 160-163; Conte 1994, 19-22; see also G. Williams 1982). In the middle of the fifth century, the laws that were to apply in Rome were - after a political fight between patricians and plebeians - written down on twelve bronze tablets (Leges XII tabularum). The tablets are not preserved, but we know of their content from quotations in later texts (see e.g. Poccetti and Santini 1999, 197-204; Conte 1994, 16-17). The Latin texts preserved from the first centuries of Roman literacy are mostly short inscriptions, and it is not until the second part of the third century BC that Roman literature as we know it starts; the earliest preserved literary texts date from around $200 \mathrm{BC}$ and from the second century BC. These first literary works in Latin are poetry and drama, but soon the Romans started to compose prose works as well. Knowledge of Greek language and literature was of great importance for an educated Roman from the third century BC until the last centuries of Antiquity (see e.g. Conte 1994, 16, 81-82, 715-717; Reynolds and Wilson 2013, 19; see also Marrou 1948, 29-61).

\subsubsection{Literary norms}

Literary norms were created for both Greek and Latin, and for both prose and poetry, in the respective classical periods (fourth century BC for the Greeks and first century $\mathrm{BC}$ for the Romans). These norms, which were based on a canon for the various kinds of literature and were taught in schools, were followed to a considerable extent by the literary elite until the end of Antiquity and were of importance for liter- 
ary works in Greek and Latin even after that. As the difference between the literary norms and the forms of Greek and Latin as actually spoken grew, an increasing number of less literary texts which reflect some of the ongoing changes appear. In particular, some Christian authors in late Antiquity were inclined to accept some of the changes in the spoken languages, as this would facilitate comprehension of the teachings of the learned clergy among the unlearned congregations (see e.g. Clackson and Horrocks 2007, 183-228, 236-264; Poli 1999, 410-417; Horrocks 2014, 43-78, 210, 213-214; see also Haverling 2014).

The extent of literacy in the Graeco-Roman world is controversial, but it is clear that the ability to read was much more common than the ability to write correctly. In the Hellenistic period (after $323 \mathrm{BC}$ ), new literary genres such as the novel suggest that the ability to read was relatively common (see Hägg 1983, $81 \mathrm{ff}$., $87 \mathrm{ff}$.). In the Roman world, some regard literacy as already "quite extensive" around 200 BC (thus e.g. Conte 1994, 15), while others have estimated that less than $10 \%$ of the population could read or write (e.g. Baldi 2002, 227); for an overview of the discussion, see Harris (1989, 3-42), who estimates (e.g. $22 \mathrm{ff} .$, 331) that a relatively small part of the population could read and that an even smaller number could write during the Roman Empire. Pointing to the evidence provided by, among other things, the Vindolanda tablets from a Roman military post on Hadrian's Wall, Bowman (1991; 2003, 79-96) makes somewhat more optimistic assumptions in this respect (for further discussion, see Beard et al. 1991). We have private letters from the Roman Empire which were dictated to scribes, thus indicating lacking or partly lacking literacy, and we have private letters written in good Latin by the private persons themselves, which seem to imply a somewhat higher degree of literacy. Although it seems unlikely that mass literacy was achieved in the ancient world, by the time of the Roman Empire, a culture "characterised by the written word" had been established (Harris 1989, 196; for further discussion, see also e.g. Beard et al. 1991; Bowman and Woolf 1994; Johnson and Parker 2009). The habit of reading epic poetry and other literary works in silence instead of hearing it recited will not have been created overnight and ancient Greek and Roman literature would retain a strong oral - and aural - character for many centuries. Those who could afford it had servants reading aloud to them - not because they were not able to read themselves, but because it was more pleasant to have someone read the text aloud. In the late Roman Republic and in the early Empire, literary works were still supposed to be heard and not read silently. In imperial Rome, literary works were often "published" by public recitations (see e.g. Reynolds and Wilson 2013, 1; Salles 2010, 97-116).

\subsubsection{Developments in the Middle Ages}

Towards the end of Antiquity - in the sixth and seventh centuries - there were some serious changes in the formerly Graeco-Roman world. These changes were the 
result of political circumstances, such as the split between the Western and the Eastern Empires, the growing estrangement between the Greek-speaking and the Latin-speaking worlds, the barbarian invasions, and the collapse of the Western Empire towards the end of the fifth century AD, but also of natural disasters, such as the so-called Justinian plague, which from its outbreak around AD 540 seems to have reduced the population dramatically in certain areas. Finally, there were also cultural changes, such as the new perspective originating from the Christian faith (see e.g. Ward-Perkins 2005; Little 2007).

As a result of these changes, there was a sharp decrease in literacy and in interest in the classical literary texts for several generations. The reading, writing, and copying of books became a matter mainly dealt with in the monasteries; this activity was to some extent initiated by Cassiodorus Senator (ca. 485-585), who strongly recommended such activity to the monks in his monastery, the Vivarium in Calabria, in the late sixth century $\mathrm{AD}$. The language used in texts written during the seventh and early eighth centuries often deviates considerably from the classical standards, and there was, especially in the West, little interest in the great pagan classics of GraecoRoman Antiquity (see e.g. R. Wright 2002, 9-10; Reynolds and Wilson 2013, 53-55, 64, 80-87; Horrocks 2014, 211, 223-224). Even a few texts from the Roman period which had certainly been written in very good Latin were affected by the lack of familiarity with the classical norm when they were copied during this period: there are, for instance, traces of "Merovingian spellings" in some manuscripts of Caesar's De bello Gallico (vulgarisation). Some of the texts from the last centuries of Antiquity are therefore problematic in this respect. A frequently discussed example is the Decem libri historiarum by Gregory of Tours (ca. 538-594): the Latin is rather literary in several respects, and some very important contemporary features are lacking, but in some of the manuscripts the orthography is very unorthodox (see e.g. Buchner 1955, xxxvi-xliii; Haverling 2008; Hilchenbach 2009, 85-90).

However, around $\mathrm{AD} 800$, there is a renewal in interest in classical literature in both the East (sometimes called the "Photian Renaissance") and the West. In the West, this is connected to Charlemagne's school policies and the so-called Carolingian Renewal or Renaissance. This resulted in the realisation that there was such a difference between the current form of spoken proto-Romance languages in the Carolingian empire (rustica Romana lingua, "rustic Roman language") and the literary Latin of the Roman classics that they were actually different languages (see e.g. R. Wright 2002, 14-17). The knowledge of Latin grammar was now greatly improved, and as a result there is a growing tendency from the ninth century onwards to "improve" the Latin of certain texts from late Antiquity and the early Middle Ages and render it more in accordance with the standards of the literary language of the classical period (n ormalis ation; see e.g. Coleman 1999; Haverling 2003, 2008). In both the West and the East, the renewed interest in the classical texts resulted in the production of many new manuscripts containing such texts - very often, the oldest preserved manuscripts containing such texts are from the ninth or tenth cen- 
turies, and in other cases the preserved manuscript tradition can be traced back to a lost manuscript from this period (see e.g. Reynolds and Wilson 2013, 58-66, 9193, 96-103; Gastgeber 2003, 28-29).

After a certain decrease in the cultural level of the Latin world in the tenth century, there was a new cultural renaissance around 1100, when the earliest universities were founded and a considerable amount of important Greek philosophical and technical texts were translated into Latin from Greek and Arabic. The scholastic movement, newly arisen in the universities, was focused on theological, philosophical, and logical problems, but not on classical literary culture (see e.g. Reynolds and Wilson 2013, 107-122). In the late Middle Ages, this new culture was challenged by a new cultural outlook inspired by a renewed interest in the pagan classics: this is the Italian Renaissance, which starts in the fourteenth century and gains full force in the fifteenth, and which leads to a renewed interest in the classical texts in both Greek and Latin as well as in the literary Latin of the classical period, which was now regarded by some as the model to follow. The new interest in Greek language and literature received further impetus when learned Greek refugees arrived in Italy with their books at the time of the fall of Constantinople in 1453. Another change in connection with the late Middle Ages and the Renaissance is the growing number of educated private persons - already in the twelfth century, there had been a marked increase in lay literacy, and this tendency grew stronger. As a result, literature and learning were no longer a matter almost exclusively dealt with by the Church (see e.g. Reynolds and Wilson 2013, 112, 123-155; Gastgeber 2003, 36-37). The influence of the printing press is considered below (1.4).

\subsection{Transmission of texts}

Sinéad O’Sullivan

This section focuses primarily on the transmission of written texts: the types of media in which texts circulated, the complex nature of manuscript culture, and the process of copying texts, as well as some of the basic terminology associated with the practices of copying.

\subsubsection{Oral and written transmission}

The heading "transmission of texts" points towards a first subsection on oral vs written transmission. Already noted (see 1.1) have been both the oral transmission of the Homeric poems, which contain stock phrases underscoring their oral-formulaic composition (Parry 1930, 73-148; Lord 1960; Skafte Jensen 1980, 9-10), and the aural character of Graeco-Roman literature, which accords with the role of oral cul- 
ture in Antiquity, evident not only in the archaic and classical periods, but also in imperial Rome, where public recitations of literary works, the dictation of letters and other kinds of texts, and the use of readers demonstrate that the Greek and Roman elites "retained a strong element of orality in their lives" (Harris 1989, 36). More recently, scholars have foregrounded the variety of ancient literary practices and have seriously questioned the assumption that orality was the dominant form of reading practice (Johnson and Parker 2009; Johnson 2010). Interestingly, the oralaural character of textual transmission finds a reflex in the mediaeval world, where, for instance, certain kinds of texts were rooted in 'a 'monastic present' in which the correct oral performance of liturgical and other texts was a crucial component of everyday life” (Grotans 2010, 63).

With regard to the preservation and circulation of texts, written transmission was vital. Key developments were the transition from roll to codex; the promotion of the written word through the foundation and expansion of libraries (e.g. under the Ptolemies in Alexandria and the early Empire); and the standardisation of texts by the Alexandrian scholars, for instance by Zenodotus of Ephesus (ca. 325-ca. 270 BC) and Aristophanes of Byzantium (ca. 257-ca. 180 BC; Dickey 2007, 5). The text-critical efforts of the Alexandrine grammarians were important for establishing canonical written texts (see 2.1.2). Also significant for the transmission and reception of texts were the production of extensive commentaries, especially in the late antique period, and their reuse and appropriation in the Carolingian age (Zetzel 1975, 336; Werner 1998, 172). These commentaries often transmitted excerpts from earlier works. Their importance is, for instance, strikingly evident in early mediaeval glossed Virgil manuscripts, where compilers extracted information from the major commentaries available on the poet. Above all, as we shall see, the written transmission of texts was far from straightforward, subject as it was to the additions, revisions, and transformations of contemporary and later scribes and editors, as well as to the relatively fluid nature of textual transmission in a manuscript book culture. The material aspects of written transmission, discussed below, are thus essential for understanding the dynamics of textual transmission in Antiquity and the mediaeval world.

\subsubsection{Media transmitting texts}

Over the centuries, many different kinds of media have been used to transmit texts, ranging from tablets to scrolls and codices. As for the writing materials, stone, slate, birch bark, papyrus, parchment, and paper have all been deployed (Bischoff 1990, 13-16). For example, wax tablets made of wood and covered with wax were used in Antiquity and the Middle Ages. Two of the most important media transmitting texts were the volumen and the codex. The former denotes a book in roll format that was made from papyrus, leather, parchment, or paper. The scroll is unrolled to reveal one page at a time and was the standard form of transmitting texts in Antiqui- 
ty. In the early centuries of Christianity, the scroll was replaced by the codex, a development of enormous consequence for the history of the book. Less fragile than the papyrus scroll, the codex or caudex, meaning "trunk or stem of a tree", denotes a book made from sheets of papyrus, parchment, or paper. It evolved from Roman wooden writing tablets. In a codex, folios were gathered together and formed into gatherings or quires comprising two double folios (binio), three double folios (ternio), four double folios (quaternio), and so on. These quires were often bound between wooden boards. The term "codex" is generally used for manuscripts, that is, for handwritten books produced before the invention of the printing press. Derived from the Latin words manus, "hand", and scribere, "to write", manuscripts were written on papyrus (made from the papyrus plant and commonly used in Antiquity), parchment or vellum (made from animal skin and widely used from the third century onwards), and paper (a Chinese invention attested in the Latin West by the eleventh century). Manuscripts could be in different formats (scroll or codex) and transmitted all kinds of material, ranging from written texts to illustrations, diagrams, notes, colophons, and marginalia. Premodern texts circulated primarily in manuscript witnesses, examination of which is central to the study of the reception of an author or text. The term "manuscript" is also applied to the final version of a modern text before it has been printed.

Parchment was extremely expensive and manuscripts were, therefore, sometimes reused, as in the case of palimpsests. The word "palimpsest" derives from

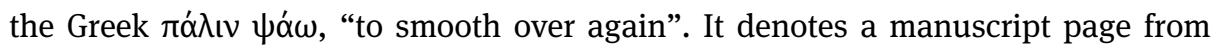
which the original text has been effaced, that is, the writing surface has been scraped or the text washed off in order to prepare it to be reused for another work which is superimposed on the earlier text. Usually, the economic value of parchment was a primary motive for the reuse of writing material made from animal hides. Modern decipherment of the original text generally relies on ultraviolet light and photography rather than on chemicals, which can be quite damaging to the parchment. A famous example of a palimpsest manuscript is the Codex Nitriensis (cf. fig. 1.2-1), written on palimpsest leaves taken from manuscripts of the Iliad and the Gospel of Luke and from a seventh- or eighth-century manuscript of Euclid (London, British Library, Add. 17210 and 17211).

Mediaeval manuscripts were sometimes composite entities, comprising different codicological units. They could transmit contemporary and homogeneous elements, or comprise heterogeneous sections, sometimes dating from the same or different periods (Andrist, Canart, and Maniaci 2013). Composite manuscripts are the result of many factors. For instance, the interests of an owner or the content of a manuscript could dictate what was added to a manuscript. Equally, replacement of a lost part of a codex sometimes resulted in the inclusion of a fascicle for a missing section. By way of illustration, we may note two examples. The first is a ninth-century manuscript, London, British Library, Harley 2782, comprising two codicological units, which together provide commentaries on all of the major works of Virgil (O’Sullivan 


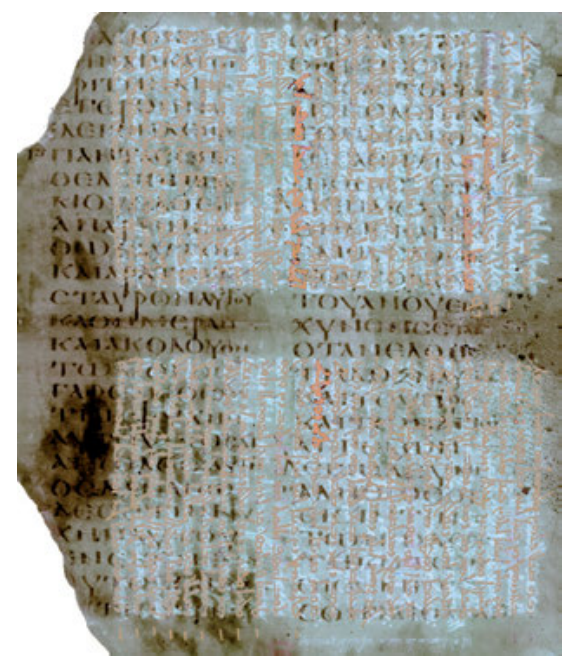

Fig. 1.2-1: Codex Nitriensis, f. 20r, showing the upper Syriac text and the effaced Greek text of the Gospel of Luke under ultraviolet light. Source: commons.wikimedia.org/w/index.php?title= File:Codex_Nitriensis,_f.20r_(Luke_9,22-33).jpg\&oldid=129699031.

2016). The second is another ninth-century manuscript, Paris, Bibliothèque nationale de France, lat. 10307 + Città del Vaticano, Biblioteca Apostolica Vaticana, Reg. lat. 1625 (III), which consists of two contemporary and homogeneous elements that transmit Christian and pagan works (Munk Olsen 1985, 764-765; Bischoff 1998-2017, no. 4627, 3:160-161). The first element (f. 1-43) transmits Caelius Sedulius' Carmen Paschale flanked by Juvencus' Evangeliorum libri quattuor, the second (f. 44-245) the works of Virgil surrounded by the commentary of Servius. Many factors suggest that the different sections of the manuscript were part of the same enterprise (format, ruling, script, decoration). All kinds of material are found in the manuscript, which contains classical, late antique, and mediaeval texts, commentaries, and excerpts (e.g. from Homer, Ennius, Sallust, Virgil, Pseudo-Ovid, Servius, Pseudo-Dares Phrygius, Priscian, Caelius Sedulius, Juvencus, Alcuin, and John Scottus Eriugena). Interestingly, the pagan material sits comfortably alongside the Christian.

Occasionally, only a part or parts of a manuscript survive (Brownrigg and Smith 2000). Manuscript fra g m en t s can vary in size. In some instances, a single leaf or a strip of parchment is all that remains. Fragments of mediaeval manuscripts may be dispersed across several libraries. There are many reasons, material and historical, that result in a manuscript becoming fragmentary or being taken apart. These include lack of interest in a work and material damage. The latter may have happened in the mediaeval, early modern, or modern periods, as illustrated by the Cotton Library fire (1731) and the bombardments of World War II. Some fragments only survive because of their reuse as binding material. In other cases, the interests of collectors resulted in fragments of a manuscript being divorced from its original 
setting. An example is that of the German scholar Karl Bernhard Stark (1824-1879), in whose collection we find a fragment of a ninth-century glossed Virgil manuscript (Ottaviano 2013, 222-223). Given Stark's interest in Roman antiquities, it is no surprise that he should have included this fragment in his collection (München, Archäologische Staatssammlung, Bernhard Starks Collectaneen, his. Ver. 18, VIII, f. 693694). Fragments might seem less useful than complete codices because they contain less text, but this is not the case. In fact, fragments sometimes provide clues as to the circulation of a work. They can also help in dating a work extant only in later codices, as illustrated by the Lorsch fragment of the Waltharius, the oldest witness of the Latin poem (Bischoff 1998-2017, no. 1491, 1:311; Turcan-Verkerk 2016; see also fig. 1.2-2 below). And, of course, fragments may be the only witnesses of otherwise lost readings in a text.

Additionally, manuscripts can be lacunose. The Latin word lacuna, meaning "pit, hollow, gap", denotes a gap in a manuscript. Lacunose manuscripts usually have missing sections of text or commentary. The causes are many. As physical objects, manuscripts frequently suffer all kinds of accidents and material damage. Consequently, there may be loss or damage to the content of manuscripts. Material damage, for instance, may be the result of fire, fungi, insects, rodents, or water. Furthermore, quires may be misplaced or lost because of bad binding or accidents. A fascinating example, and one that has produced irretrievable loss, is the case of the Cantar de mio Cid, extant in a lacunose codex unicus (Madrid, Biblioteca Nacional, Ms. Sig. v.7-17; Montaner 2018).

Clues as to the production and material history of a manuscript may be furnished by a colophon, that is, the inscription or short account at the end of a

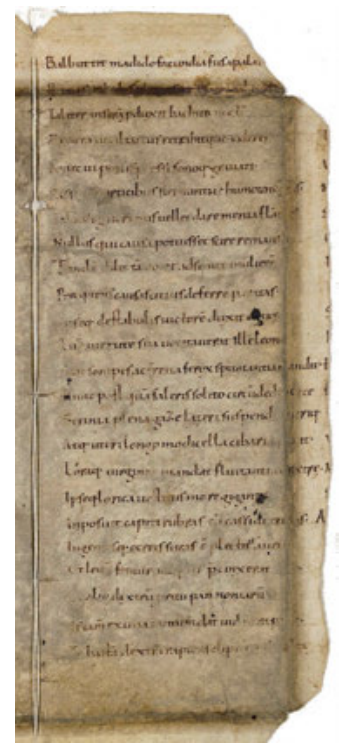

Fig. 1.2-2: One of the Waltharius fragments from Lorsch (Hamburg, Staats- und Universitätsbibliothek, Cod. 17 in scrin.). Source: bibliotheca-laureshamensis-digital.de/view/subhh_ codscrin17_fragm1/0003). Image: CC-BY-NC-ND. 
manuscript or book. An invaluable and extensive collection of occidental colophons is that published by the Benedictines of Bouveret (1965-1982). The colophon may provide information about the scribe, the printer, or the person who commissioned, bought, or sold the manuscript or book. As such, it is often a source of historicogeographical and cultural information. For instance, in a humanistic manuscript there appears the colophon of a scribe named Statilius Maximus, whose identification is debated and who is generally seen as operating in the second century CE. The colophon, found in Poggio's manuscript (Città del Vaticano, Biblioteca Apostolica Vaticana, Vat. Lat. 11458), furnishes information about the scribe's correction of Cicero's De lege agraria and his use of various revisions (Schiegg 2016, 131). Moreover, in the famous Lindisfarne Gospels, an Old English colophon lists those involved in the manuscript's production (Schiegg 2016, 132). In some instances, colophons provide clues as to the existence of ancient but otherwise largely unknown authorities (Cadili 2008, 204; Herren 1999, 55-61, 67; Miles 2011, 32).

\subsubsection{The manifold elements in mediaeval manuscripts}

As material objects and text-carriers, manuscripts housed all kinds of elements, providing different types and layers of information (Géhin 2005). For instance, in the "long twelfth century", texts in the following fields circulated widely: liturgy, theology, classics, medicine, law, and the sciences (Kwakkel and Thomson 2018, 4). Texts often attracted accompanying material: commentaries, glosses, diagrams, illustrations, decoration, musical notation, scholarly and personal notes, codes, signs, symbols, captions, headings, titles, subtitles, syntactic markers, and corrections (Kwakkel 2018; Steinova 2013). Two examples should illustrate this phenomenon. The first is the emergence of the sequence c ommentary in the twelfth and thirteenth centuries (Kihlman 2006). Mediaeval commentaries on sequence texts, that is, chants sung before the recitation of the Gospel during the Eucharist, represent a new genre that is found in both monasteries and cathedral chapters. Such expositions often incorporate a whole range of different kinds of text: the introductory section or prologue, the sequence, the commentary text, and even, at times, interlinear annotations. Sequence commentaries sometimes quote the incipit of the strophe or strophes they are elucidating; at other times, they include the sequence text itself, either as a complete text or broken up or intertwined with the commentary. The sequence text may precede the commentary or be found alongside it on the same page. As for the nature of sequence commentaries, their character is diverse in scope, ranging from philosophy and theology to grammar and vocabulary. The second example consists of glosses, which sometimes circulated as textual traditions. A gloss may be in a classical language, in the vernacular, or even in Tironian notes, an ancient form of stenography. The functions of glosses range from grammatical and explanatory elucidation to the provision of encyclopedic and allegorical interpretation (Wieland 1983; Teeuwen 2010; O’Sullivan 2017a, 2017b). Glossators often assembled informa- 


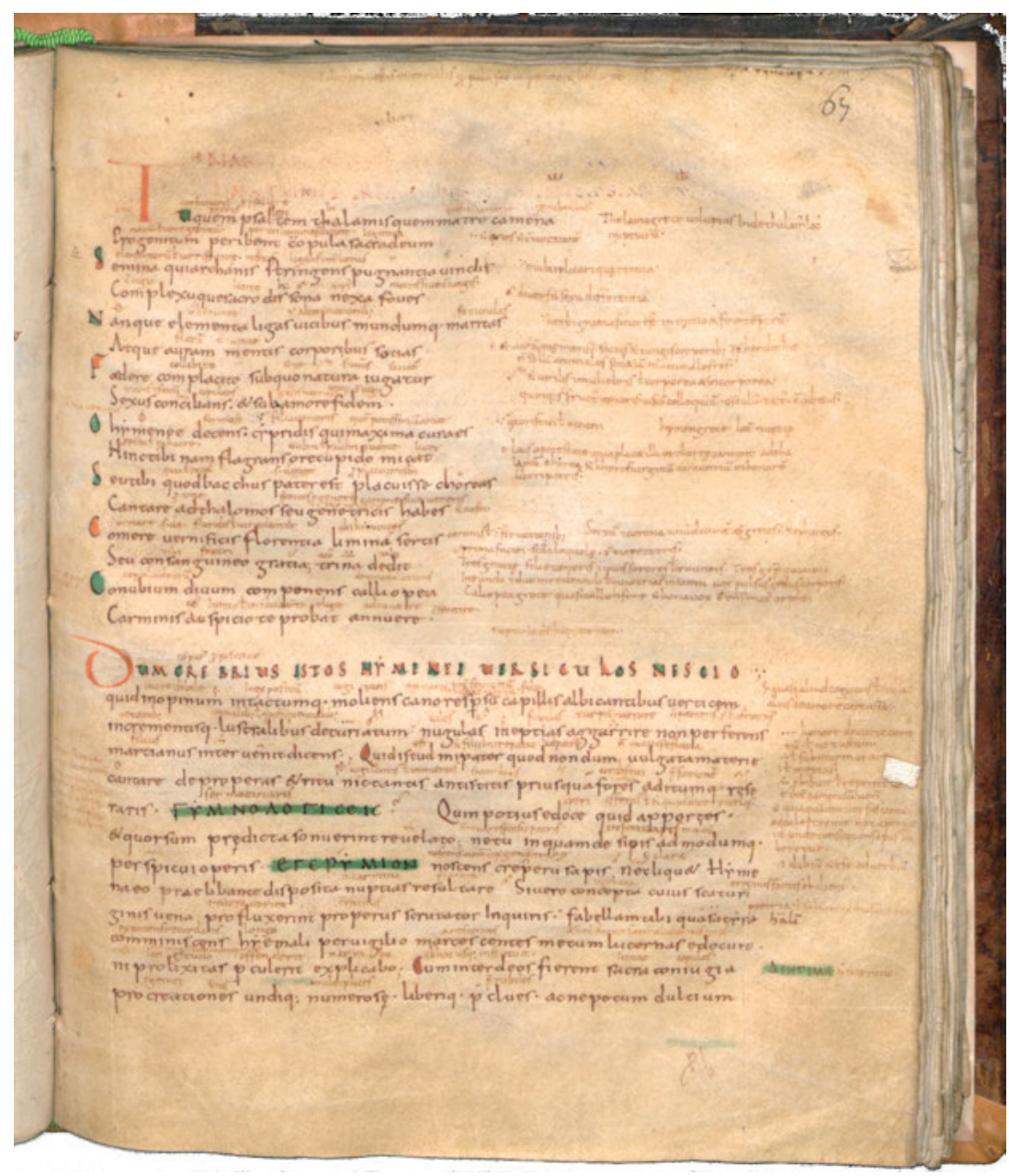

Fig. 1.3-3: A glossed manuscript page with marginal and interlinear annotations (Trier, Bibliothek des Priesterseminars, Ms. 100, f. 67r). The manuscript is a parchment manuscript dating to the ninth and tenth centuries and transmitting glosses from the oldest gloss tradition on Martianus Capella. Image: CC-BY-NC.

tion. They not only gathered materials but also collated, paraphrased, condensed, and cross-referenced sources. At times, glosses exhibit the vitality of the encyclopedic tradition with its age-old antiquarian priorities of excerpting, summarising, synthesising, and citing authorities. Glosses often circulated in major centres of learning, were used by prominent scholars, and were quarried for compendia of all kinds. In the case of a ninth-century glossed Virgil manuscript, Montpellier, Bibliothèque interuniversitaire, Section Médecine, H 253, a number of glosses show overlap with various mediaeval compilations such as the Liber glossarum and the mythographic collection by the author known as the First Vatican Mythographer (Ottaviano 2013). 


\subsubsection{The copying of texts}

The practices deployed by ancient and mediaeval scribes when copying texts provide insight into how the tradition of a text was established. At the heart of transmitting texts was the copyist, also known as the scribe. While all copyists were scribes, not all scribes were copyists (a scribe could also be the author of a document). Scribes in the early Middle Ages were primarily to be found in monastic or ecclesiastical centres. The identity of most remains uncertain. Palaeographical clues, however, can provide insight into the home of a scribe. For example, in a fragmentary Virgil manuscript from St. Emmeram, the principal gloss hand has been characterised as writing a "Celtic minuscule". Bernhard Bischoff (1960, 219220) suggested Wales or Cornwall as the home of the scribe. Noteworthy is the fact that the same hand has been identified in other ninth-century manuscripts either linked with St. Emmeram or originating at the abbey. In some instances, we know the name of the scribe who may be the author of the text. The term "autograph" is used to denote a manuscript written by the hand of the author. Usually, however, authors did not write down or copy their own work themselves. More commonly, works were written down under the supervision of the author. For ancient and mediaeval works, then, autographs are a rarity. An interesting example is furnished by John Scottus Eriugena's Periphyseon in Reims, Bibliothèque municipale, 875. Believed, in part, to be the autograph of Eriugena, the manuscript, written by several hands, is perhaps most illuminating for the insight it furnishes into the practices of revis i on (L. Smith 1992, 55).

An important term associated with scribal activity is the all-encompassing word documentum (doceo + -mentum), meaning "teaching, instruction, or an example". The term derives from the verb doceo, "to tell, inform, instruct, demonstrate, show, teach". It primarily designates something that is inscribed or written. A document transmits evidence, information, or a text such as a charter, treatise, inscription, or official paper. A document can also be the instrument on which information is recorded. In the course of transmitting written documents, wit ne s s e s were produced, and these too are documents. The term "documentary" also occurs in an important distinction made by palaeographers, namely between "book hands" and "documentary hands". The former denotes the plethora of formal handwriting scripts circulating in the ancient and mediaeval worlds, the latter the array of cursive scripts written with a running hand.

Texts generally survive in manuscript witnesses. A distinction is made between direct witnesses, that is, copies or prints of a work, and indirect witnesses, which may be paraphrases, summaries, translations, or simply references to a work (see 4.5.1). An indirect witness (see 3.2) can consist of quotations or portions of a work in later texts, as in the case of Rabanus Maurus' De rerum naturis, which includes much of Isidore's Etymologiae. Texts are usually extant in co pi es. Here, the terms "apograph" and codex descriptus are important ones. The first derives from 


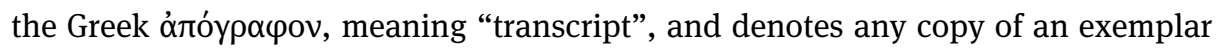
(which may also be lost); the second refers to a copy derived from another extant manuscript (see 4.3.3). Crucially, texts were regularly transcribed in manuscript copies that frequently served as ex emplars for further copies. Various methods were deployed by scribes to copy texts. Ancient and mediaeval texts were sometimes copied by dictation, that is, a copyist or copyists wrote down that which was read aloud or dictated to them. More commonly, scribes copied texts visually from an exemplar or exemplars, that is, from an older manuscript or manuscripts. The term "exemplar" denotes a text that has been copied or transcribed into a new manuscript witness. A copy, in turn, can serve as the exemplar for another copy (for an example of a series of exemplars and copies whose existence can be inferred, see 1.4.2 below on the transmission of Lucretius). The term "ex e m plar s hift" denotes the practice of shifting between exemplars, that is, the use of several exemplars for different sections of a text (see 4.4.4.2). In textual scholarship, exemplar shift is one form of contamination. The term "contamination" denotes the combination of readings from more than one exemplar. In the field of textual criticism, contamination presents real challenges for the modern editor (see further 4.4).

In the process of copying texts in the ancient and mediaeval worlds, errors and misreadings of all sorts emerged. For a typology of all errors, Louis Havet's classification (1911) is seminal. A few examples should illustrate the problems that often emerged in the process of copying texts. For instance, there was omission of text due to haplography and the addition of text due to dittography, that is, when a copyist repeated a letter, word, or phrase. In the case of haplography, a scribe omitted a section of text by inadvertently skipping from a word/words in the text to a similar word/words further on in the text (details in 4.3). Later copyists sometimes sought to correct such errors and establish the integrity of the text. For example, they corrected the errors of earlier scribes by filling in lacunae, that is, by supplying the omitted words either in the interlinear or marginal spaces.

\subsubsection{Types of text transmission and editorial choices}

Modern editors regularly confront the many difficulties presented by the transmission and circulation of ancient and mediaeval texts. Working with all kinds of works (e.g. multilayered texts, texts that can be classed as fluid, non-authored texts, glosses, lemmatised commentaries, and works that are the result of collective authorship), they endeavour to produce editions that sometimes present an earliest form, sometimes underscore an ongoing process, and sometimes seek to capture an entire tradition (Iversen, in Göransson et al. 2016, x; Göransson 2016, 405). For a discussion of some of the principle types of editions, see section 6.1. Challenges, however, are continually posed by the various forms in which ancient and mediaeval texts survive, as well as by the practices of ancient and mediaeval scribes. This has led 
to scholarly debate on how best to edit all kinds of texts, especially ones that defy the traditional method of Lachmannian genealogical recensio (see 6.2). Interesting solutions have been suggested. For instance, Alexander Andrée proposes an expanded single-manuscript edition of the Glossa ordinaria on the Gospel of John, Barbara Crostini an electronic edition of the interrelated visual and textual material in a Greek catena on the psalter extant in a single manuscript witness, Greti DinkovaBruun an edition of the original text and later versions of a section of Peter Riga's commentary on the Bible surviving in several hundred manuscripts, and Andrew Hicks a synoptic edition of the anonymous late mediaeval commentary tradition on Martianus Capella (Göransson et al. 2016). The obstacles are manifold, requiring all kinds of possible solutions to underscore the creative and dynamic nature of textual transmission in a manuscript culture.

\title{
1.3 Book production and collection
}

\author{
Outi Merisalo
}

The impact of the modalities of book production on the transmission of texts is still often ignored by editors of texts with little interest in book history, including palaeography, codicology, and library history. The subsequent media revolutions (passage from the rotulus to the codex form, introduction of the Carolingian minuscule, invention of the art of printing, and so on) have, however, deeply influenced what was transmitted and in what form. This chapter will outline the development of book production and collection from Antiquity to the modern period.

\subsubsection{Book production and libraries in Antiquity}

The earliest information on mechanisms of book production in ancient Greece comes from fifth-century BC Athens. Normally, the author would be responsible for having the work both copied and distributed, but there is already evidence of commercial booksellers. Book production is evidently connected to the intense debate about the general desirability of books, which pitted the Sophists, who are in favour of the written word, against figures such as Plato and Aristophanes, convinced of the deleterious effect of written transmission on how individuals analyse, internalise, and interpret ideas. According to the latter, written culture encourages superficiality as memorising is no longer necessary.

From the seventh century BC onwards, the book form of the Greek world had been the papyrus rotulus. Since the material was exclusively produced in Egypt, its availability in other regions was, of course, subject to fluctuations in imports connected to war and so on. The earliest evidence for book collections in the Greek 
world goes back to the sixth century BC (Nielsen 2006). In late fifth-century Athens, such figures as the politician Euclides (archon, 403-402 BC; König, Oikonomopoulou, and Woolf 2013, 87) were known to have a private library. In the fourth century, private collections increased in number and size, for example Aristotle's considerable library in the Lyceum grove in Athens (Vössing 2006). In the same period, commercial book trading covered not only mainland Greece but also southern Italy (Magna Graecia) and Sicily in the west, as well as Asia Minor as far as the Greek cities of the Black Sea in the east.

With the fragmentation of the short-lived empire created by Alexander the Great (356-323 BC), the successor states ruled by dynasties established by his generals, such as Seleucus, Antiochus, and Ptolemy, consolidated a new political, cultural, and linguistic reality characterised by the status of Greek as a new all-round language of communication in the Middle East. The libraries established by Hellenistic rulers were prevalently public in nature (Vössing 2006). From the point of view of book collections, the establishment of the Mouseion (Movocĩov) research centre and library by Ptolemy I Soter and Ptolemy II Philadelphus in Alexandria at the beginning of the third century took library collections to a new level. Despite the traditional name associated with the cult of the Muses, there is no obvious model for this research centre with a well-appointed library. Ptolemy I, appreciative of learning just like Alexander, who had been taught by Aristotle himself, recruited the Peripatetic philosopher Demetrius of Phaleron, another disciple of the Stagirite, as administrative counsellor. The research centre, organised as a cult association with a priest as head and scholars as members, was financed by the state. In addition to the library, the Mouseion housed an observatory as well as zoological and botanical collections. The scope of the library was to make available the knowledge of the whole world, oikou $\varepsilon^{\prime} v \eta$, in Greek and, when necessary, in translation (e.g. the Septuagint, the Greek translation of the Old Testament; Glock 2006). Both editorial techniques (philology; Zenodotus of Ephesus, ca. 325-260 BC) and scholarly bibliography were developed, especially by Demetrius of Phaleron. The collections were accessible to rulers and members of the Mouseion. Contrary to what has been believed (e.g. Plutarch Caesar 49), the Mouseion library was not burnt down during the civil war between Caesar and Pompey. The fire in Alexandria's harbour only destroyed a book depository, not the entire library, in 47 BC (Vössing 2006). From Augustus onwards, the Mouseion was subsidised by the emperors and pursued its original mission well into the third century AD (Glock 2006). The collection survived virtually unscathed until the rebellion of Zenobia, queen of Palmyra, in ca. AD 270, when the palace quarter was destroyed (Glock 2006). Ptolemy III had established another library in Alexandria, the Serapeum, for religious, non-Greek texts; it is probable that this library assumed most of the functions of the Mouseion after AD 270. It was closed down by Emperor Theodosius in 391 (Glock 2006). The last known scholar of the Mouseion was the mathematician and astronomer Theon at the end of the fourth century.

Ptolemy III and Berenice II established the Ptolemaeum, a gymnasium with a library, in Athens in the third century BC, and Attalus I an institution specialising 
in bibliography and bibliophily, evidently modelled on the Mouseion, in Pergamon in ca. 200 BC (Clayman 2014, 140; Vössing 2006).

While the Latin language was committed to writing as early as the seventh century BC, book culture seems to have spread but slowly outside official circles and the upper echelons of society (Petrucci 1992, 35-36; see also 1.1.1 above). The situation radically changes in the second century $\mathrm{BC}$, when, through conquest, the Romans come into direct contact with the Hellenistic culture described above. On the Italian peninsula, even the prosperous upper classes of the towns become increasingly literate. Important libraries of the East are brought to Rome as booty, such as that of Perseus, king of Macedonia, by L. Aemilius Paullus after the battle of Pydna in $168 \mathrm{BC}$, and that of the philosopher Apellicon, who acquired parts of the libraries of Aristotle and Theophrastus, appropriated by Sulla during the conquest of Athens in $86 \mathrm{BC}$.

In the first century $\mathrm{BC}$, there is ample evidence for both private and public libraries. While volumes of early Latin-language literature, such as the translation of the Odyssey by Livius Andronicus (ca. 284-ca. 205 BC) and the epic poetry of Quintus Ennius (239-169 BC), seem to have been difficult to find, knowledge of Greek language and culture, as well as owning books, seems to have become an essential element of the education of middle- and upper-class Romans. Furthermore, in the first century, with formal schools becoming increasingly common, the need for books increased. Private libraries, such as those of Cicero (106-43 BC), who had Greek- and Latin-language collections not only in his city residence on the Palatine Hill but also in his houses in Tusculum, Cumae, and Antium, are well documented (Vössing 2006). From the early imperial age onwards, there is ample evidence (e.g. Petronius, Seneca, Pliny the Younger, Juvenal, and Martial) for different phases of publishing: first, both private and public readings of work in progress, then copies made for friends, and finally commercial publishing. The copies were produced either through dictation or visual copying, or a combination of both methods. Commercial publishers employed a large number of scribes producing copies contemporaneously. A corrector controlled the quality of the output, though complaints about the bad textual quality of Latin books abound (e.g. Cicero Epistolae ad Quintum 2.5.6; Martial Epigrammata 2.8.1). By the end of the first century AD, a good distribution network covering all of the Empire catered for the needs of customers.

While the constant increase in private libraries (Persius, Martial, Silius Italicus, and Pliny the Younger, among others, in the first century AD) testifies to the appreciation of book culture among the upper classes, from the first century BC books also became increasingly accessible through the establishment of public libraries, the first of which were those of the politician and historian C. Asinius Pollio in the Atrium Libertatis near the Capitoline Hill in 39 BC, with Greek- and Latin-language sections (P. L. Schmidt 2006; Förtsch 2006; Nielsen 2006), and, even more importantly, of his friend Octavian, soon to become Augustus, near the temple of Apollo on the Palatine in 28 BC (Nielsen 2006). At the beginning of the second century AD, 
Emperor Trajan placed two libraries on his Forum, one for Greek- and the other for Latin-language books. By the mid-fourth century AD, there were twenty-eight or twenty-nine public libraries in the city of Rome (Nordh 1949, §97.9; Brodersen 2006; but see Vössing 2006 on doubts regarding the number).

\subsubsection{Libraries and archives in late Antiquity and the Middle Ages}

Book production radically changes from the fourth to the sixth century AD with the legalisation and triumph of Christianity after the Edict of Milan (AD 313). Whereas commercial editing houses at first compete successfully with well-established Christian structures based on parish and diocesan writing centres, by the sixth century the latter prevail even in the Eastern Empire. Until the end of the Byzantine Empire (1453), the state maintains the imperial library, whereas the political complexity of the former Western Roman Empire after AD 476 is reflected in the book production carried out by the monastic scriptorium (Binder 2006; for the development of the scriptorium throughout the Middle Ages, see Gamper et al. 2015).

Thanks to the triumph of the Benedictine Rule (sixth century; for St Benedict, see Böckmann 2006), which incorporates the copying of books into the monastic way of life as part of bodily work, and the authoritative defence of ancient nonChristian literature as part of Christian culture by a series of important ecclesiastics such as Cassiodorus (sixth century), monastic communities form important book collections of both ancient and contemporary works. These collections, which ensure the transmission of ancient texts that had survived the book-format revolution (see 1.2.2), are continuously enriched and renewed, facing new challenges such as the next media revolution: the adoption of the Carolingian minuscule in the late eighth and early ninth centuries, an essential instrument of the reforms carried out by Charlemagne (r. 768-814) in his new Roman Empire of the West (Bischoff 2009, $179 \mathrm{ff}$.). In fact, the vast majority of manuscript volumes preserved until modern times date from the period after the eighth century (Bozzolo and Ornato 1980, 84). In the Carolingian Empire, subsequently divided into three parts at Verdun in 843, the thriving monasteries, such as Corbie, Fleury, Tours, and St Gall, among others, are an essential part of the economic, cultural, and religious structures of society, with their scriptoria disseminating texts deemed important in the new script (Bischoff 1961-1981; Pellegrin 1988). Charlemagne's court library, no doubt modelled on the Byzantine imperial one, is part of the network of libraries ensuring the dissemination of texts in the new medium. The texts not considered worth recopying have a high probability of disappearing in the subsequent centuries, when Carolingian minuscule, a kind of trademark of the Western Church and western feudal society, spreads even in newly (re)conquered areas such as the Iberian peninsula from the year 1000 onwards, and in the territories acquired by the Church of Rome in eastern and northern Europe. 


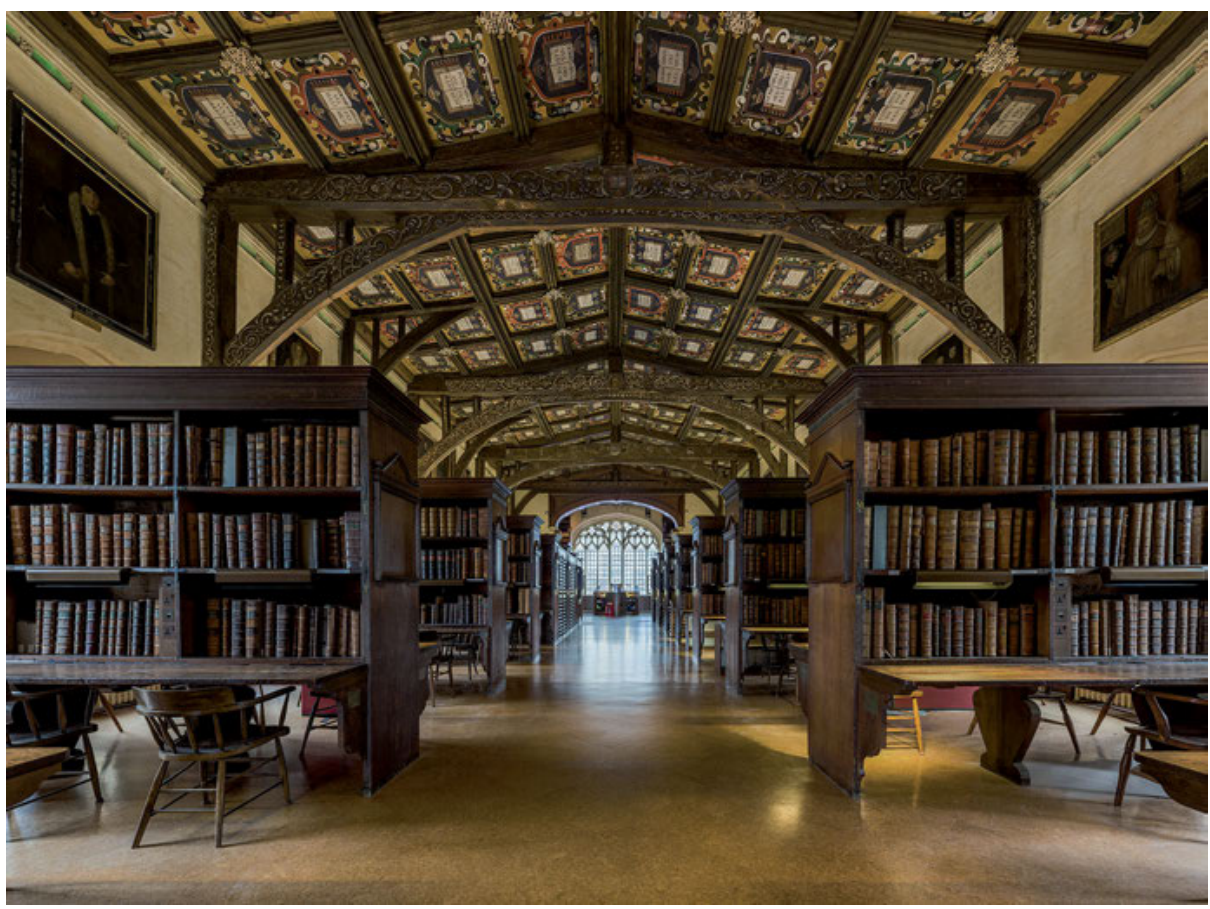

Fig. 1.3-1: Duke Humfrey's library in the Bodleian Library, Oxford, dating from the late fifteenth century. Source: commons.wikimedia.org/w/index.php?title=File:Duke_Humfrey\%27 s_Library_Interior_6,_Bodleian_Library,_Oxford,_UK_-_Diliff.jpg\&oldid=269845871.

It is only with the establishment of the universities as ecclesiastical institutions in the twelfth and thirteenth centuries that the position of the scriptorium changes. Some monastic scriptoria successfully compete for the book market with new secular ateliers. The latter abound not only in university cities, such as Paris, Oxford, Cambridge, Bologna, and Padua, where secular scribes reproduce university texts through a highly efficient system of multiple copying based on the rental of peciae (each containing a relatively short segment of text; see Murano 2005), but also elsewhere, to address the needs of the new, dynamic bourgeoisie gaining access to literacy. Universities, such as the Collège de Sorbonne or Balliol College in Oxford, actively develop book collections both through acquisition and through donation (Delisle 1868, 180-182; Nebbiai, Angotti, and Fournier 2017; Mynors 1963, 247; Merisalo 2012, 108). These collections are accessible to members of the community but in many cases also to outsiders. From the thirteenth century onwards, princely, royal, and imperial courts, and indeed the papal Curia (Manfredi 2010), develop increasingly important book collections, seen as an essential element of the prestige of the ruler. Cases in point are, for example, the libraries of the kings of France and England, several times dispersed and reconstituted in the last centuries of the Middle Ages, those of the dukes of Burgundy in the fifteenth century, and the Vatican 
Library, also incorporating remnants from earlier papal libraries, officially established as a public library in 1475 by Sixtus IV (Manfredi 2010, 199-225). In Florence, in addition to the private library of the Medici, the library of the humanist luminary Niccolò Niccoli (d. 1437) is opened as a public library thanks to the financial input of Cosimo de' Medici the Elder (Ullman and Stadter 1972). Even north of the Alps, important private libraries are assembled, such as that of Hartmann Schedel (d. 1514), a Padua-educated humanist physician and author of a Latin Cronica and its German version, the Weltchronik (1493), who seems to have allowed other scholars to use his collection (Stauber 1908; Wagner 2014; Merisalo 2016, 830).

\subsubsection{Libraries and archives in the modern period}

With the advent of printing in the second half of the fifteenth century, both book production and book collections enter another period of revolutionary change. The new ars artificialiter scribendi, incomparably cheaper than handwriting due to the elimination of the salary of the scribe, supersedes the traditional modes of production by the end of the century. As regards transmission of texts, this media revolution constitutes another bottleneck: the texts not deemed interesting are not transferred into the new medium and risk disappearing. Libraries react to the media revolution by actively purchasing printed books: for example, the library of the Collège de Sorbonne establishes, in addition to the manuscript collections, a special section of printed volumes that will continue until the seventeenth century (Delisle 1868, 200). The Reformation, with the abolition of monasteries, sets the old monastic collections in flux, with handwritten books either wandering into other libraries or being recycled in, for instance, bindings (e.g. in the kingdoms of Denmark and Sweden: approximately 50,000 manuscript fragments; see Ommundsen and Heikkilä 2017). Texts only preserved in old handwritten books constitute objects of interest for historians for centuries to come, such as Jacques Bongars (1554-1612), whose manuscripts went to the Burgerbibliothek in Berne (see burgerbib.ch/en/the-holdings/ bongarsiana-codices), and philologists, such as Pierre Daniel (1531-1604). Luxury manuscripts, still produced in the sixteenth century, have an aesthetic, representative, and financial value for their owners. Indeed, a well-appointed book collection housed in representative buildings, on a par with Wunderkammern, that develop into fully-fledged museums, is consolidated as a set part of the self-representation of political leadership, whether of kings, emperors, popes, or a republic. The old and new libraries are made more accessible through systematic cataloguing, especially from the sixteenth century onwards (e.g. the Vatican Library; Montuschi 2014, 243-543). Donations and acquisitions of entire collections make important developments possible, for example in the case of the library of the dukes, later electors, and finally kings of Bavaria (Stauber 1908). The dispersal of library holdings is also intensified by military operations. During the Thirty Years War (1618-1648), entire 
collections of handwritten and printed books are transferred as highly appreciated booty to the libraries of victorious powers, for example in the acquisition of important private and public libraries by Sweden (Walde 1916-1920) and the transfer of a large part of the Palatine Library from Heidelberg to Rome (Montuschi 2014, 279-336). In the seventeenth and eighteenth centuries, accessibility of collections is enhanced on the one hand by detailed printed catalogues, for example Bandini's catalogue of the Laurentian Library in Florence (Bandini 1774-1777, 1778; see also Siponta De Salvia 1986), and such monumental overviews of European library collections as Montfaucon's Bibliotheca bibliothecarum (Montfaucon 1739) on the other. The decades of the French Revolution and the Napoleonic era (1790s-1815) witness the transfer of ecclesiastical collections into central repositories (most systematically in France) or simply onto the book market, where they are acquired by such collectors as the Venetian Jesuit Matteo Luigi Canonici (1727-1805) or Giacomo Morelli (1745-1819), librarian of the Biblioteca Marciana (Valentinelli 1868, 136 ff.; Zorzi 1980, 235 ff.).

The nineteenth century is a period of consolidation of important state-run and institutional collections of a public nature, such as the Bibliothèque royale/de la Nation (1790)/impériale (1804-1815)/royale (1815-1849)/nationale (1849-1851)/impériale (1851-1871), and again nationale (1871-) of France, often considerably enriched through the turbulent book market of the Napoleonic era, as well as the formation of large private libraries made possible by large fortunes generated by industrialisation, such as that of Sir Thomas Phillipps (1792-1872), dispersed between the last decades of the nineteenth century and 2006 (see Munby 1951-1960; Bell 2009). In the United States, Congress establishes a library in 1800, which develops into the most important collection in the country and the national library (Cole 2018). Cataloguing and recataloguing projects (e.g. Italy: Mazzatinti 1890-2013; France: Libri et al. 1849-) enhance the accessibility of these collections, and the historicising and contextualising approach to the study of writing and book production represented by such scholars as Léopold Delisle (1826-1910; see Vielliard and Gosset 2004), Wilhelm Wattenbach (1819-1879), and, last but not least, Ludwig Traube (1861-1907; see Merisalo 2017) throws light on the formation and development of collections. Such a work as Delisle's Le Cabinet des manuscrits de la Bibliothèque Impériale/Nationale (Delisle 1868) is still the basis of any research on the manuscripts of the Bibliothèque nationale de France. The development of reproduction techniques, for example heliography and photography, also contributes to the accessibility of collections. Such an epochal political event as the unification of Italy $(1861,1870)$ forcefully impacts the book market, with the confiscation of the libraries of ecclesiastical institutions and their incorporation into state-run libraries, such as the Biblioteca nazionale of Rome, that of Florence (see Fava 1939), and the Biblioteca Marciana in Venice. Some libraries, such as the Königliche Bibliothek in Berlin, proceed to undertake vigorous acquisition campaigns, such as that of five hundred manuscripts of the Phillipps collection in 1889 (see staatsbibliothek-berlin.de/diestaatsbibliothek/abteilungen/handschriften/abendlaendische-handschriften/samm lungen/mss-phill/), among others. 


\subsubsection{Media revolution: Digitisation}

Most of the state collections consolidated in the nineteenth century continue to exist and enrich their collections in the twentieth despite the two World Wars and political upheavals. During World War I, some important collections are destroyed, such as (in 1914) the library of the Catholic University of Leuven, established in 1834, which was reconstituted with international donations only to be destroyed again in 1940 (see Coppens, Derez, and Roegiers 2005). The states emerging from the demise of such political entities as the Austro-Hungarian Empire transform previous state libraries such as the Öffentliche k. k. Universitätsbibliothek (C.k. Veřejná a univerzitní knihovna) of Prague (for the history of the older collections, see Truhlář 1905, iii-xvi) into national libraries (Národní a univerzitní knihovna, 1935-1939/Zemská a univerzitní knihovna, 1939-1941/after incorporation of other Prague libraries, Národní knihovna, 1958-; see National Library of the Czech Republic 2012). In the Soviet Union, the Imperial Public Library, established in St Petersburg by Catherine II in 1795 and forcefully developed in the nineteenth century, survives the Russian Revolution as the Russian Public Library (1917-1925)/Official M. Saltykov-Shchedrin Library (1932-1992)/Russian National Library (1992-; see National Library of Russia 2018). From the early decades of the twentieth century, the accessibility of collections is enhanced by microfilming, which had been developed in the second half of the nineteenth century and was vigorously adopted for reproductions (e.g. the microfilming of millions of pages of British Library collections by the Library of Congress, 1927-1935). Both microfilms and microfiches are still in use in 2019, guaranteeing a lifespan of approximately five hundred years when stored properly (NEDCC 2007). In addition to microfilming campaigns of individual libraries, extensive microfilm collections are created, for example that at the University of Saint Louis, Missouri, which covers more than 37,000 manuscripts of the Vatican Library as well as 3,000 of other origins (slu.edu/ library/special-collections/vatican-film-library), or that of the Institut de recherche et d'histoire des textes in Paris (IRHT; www.irht.cnrs.fr), currently containing microfilms of approximately 76,000 mediaeval manuscripts (medium-avance.irht.cnrs.fr). Accessibility is also enhanced through reproductions on paper, such as the volumes of the Catalogue de manuscrits datés, the oldest and still the most important project of the Comité international de paléographie latine, established in 1953, aiming at cataloguing, including reproductions, all manuscripts bearing the name of the scribe and/or date and/or place of copy (palaeographia.org/cipl/cipl.htm).

The great media revolution was, however, that of digitisation during the last decade of the twentieth century and in the early twenty-first century. Not only were library catalogues transferred from paper and microfilm/microfiche to online platforms in the 1990s, but intensive digitisation campaigns completely changed the accessibility of all types of formats. On the one hand, digital publications by commercial publishing houses transformed the printed collections of libraries; on the other, non-copyrighted older books and, in the 2010s, entire manuscripts became 
available free of charge through such databases as Gallica (gallica.fr; National Library of France), the digital library of the Münchener Digitalisierungszentrum (digitale-sammlungen.de; Bavarian State Library, Munich), the German database Manuscripta mediaevalia (manuscripta-mediaevalia.de), the Swiss database $e$-codices (e-codices.ch), the digitised manuscripts site of the Vatican Library (www.mss. vatlib.it/guii/scan/link.jsp), or the collaborative digitisation project of the Bodleian and Vatican Libraries funded by the Polonsky Foundation (bav.bodleian.ox.ac.uk, 2012-2017). The "Europeana Regia” project (europeanaregia.eu, 2010-2012, run by a consortium of five important research libraries) digitised some 1,000 manuscripts from Carolingian libraries (eighth to ninth centuries), Charles V and his family (fourteenth to fifteenth centuries), and the Aragonese kings of Naples (fifteenth century). Although reproductions, however good, will never supplant the original object, they make it easier to prepare for the indispensable work on originals. So far, digitisation has not induced most libraries to deny access to originals. On the contrary, a considerable increase in user-friendliness in the form of photography of original library holdings being allowed for personal research use, already common in Scandinavia, has occurred in the 2010s in such countries as France, the United Kingdom, Germany, and Italy. Thanks to these policies, library collections are today more universally accessible than ever.

\section{Acknowledgements}

The research for this article was carried out thanks to the Lamemoli project (Academy of Finland and University of Jyväskylä, no. 307635).

\subsection{Textual traditions and early prints}

Iolanda Ventura

In this section, I describe and discuss the philological practices developed by humanist and Renaissance scholars and philologists, as well as the role played by philology and textual criticism in the transition from manuscript to print. In order to do so, the focus will lie on selected examples from classical, patristic, and mediaeval literature. The way in which humanist and Renaissance scholars and philologists contributed to the transformation of culture, to the diffusion of literature through the printed editions that replaced manuscripts, and to the transition from manuscript to print - in short the transition from mediaeval to Renaissance culture - will be elucidated. Last but not least, practices and methodologies will be met which are still acknowledged or even imitated by textual scholars today. 


\subsubsection{The reception of a text as witnessed in print: Philological practices}

For the history of texts and books, the fourteenth and the fifteenth centuries are a crucial time. The intellectual approach to the book and its content, as well as the structure and the characteristics of the contemporary reference libraries, were deeply changed, on the one hand by the rediscovery of classical texts and the new appreciation of classical literature, with a corresponding estrangement of the learned elite from mediaeval works, especially from theological and philosophical works; and, on the other hand, by the invention of the printing press and the subsequent changes in the book as an object - a product resulting from new technologies - and as a medium of transmission and communication of culture and literature (Pettegree 2011; Eisenstein 2000; Hellinga-Querido 2014, 2018; Barbier 2017; Nuovo 2013; Dondi 2016). This transition also radically influenced philological practices and methods of perceiving, evaluating, and editing texts. If the changes in the intellectual approach to the book and in the image of the ideal and real library can be gauged by the return to the literary milieu of classical works that had been either forgotten or more or less deliberately put aside because of their controversial content or difficult adaptability to Christian culture, the influence of philological practices can be easily seen in the various aspects of the humanistic engagement in bringing back to light, analysing both in content and form, and publishing classical and patristic texts. Examples include Lucretius (d. ca. 55-50 BC), Celsus (ca. 25 BC-AD 50), Aulus Gellius (125/130-after AD 170), or Caelius Aurelianus (early fifth century AD).

Philology, considered both as the desire to perform a critical examination of the text and the intention to improve its quality both in form and content, existed well before humanism and the Renaissance. Textual criticism was practised, for example, by learned scholars such as Lupus of Ferrières (abbot of Ferrières during the ninth century, d. ca. 862), who glossed manuscripts, recalling some variant readings from others or suggesting better readings, or Theodulf of Orléans (poet, philologian, and bishop of Orléans, d. 821), who contributed greatly to the establishment of a corrected text of the Bible compared to the corrupt one circulating before the cultural reform initiated by Charlemagne (on reading practices during Carolingian times, see Nebbiai 2013; O’Sullivan 2011, 2017). Glossing, commentating, and improving texts became a well-documented practice during the later Middle Ages, especially in the twelfth-century schools of grammar and philosophy. Nonetheless, the dimensions of philological engagement increased considerably during the fourteenth and the fifteenth centuries, when the activity of humanist scholars expanded the available classical library and the intellectual approach to it in several ways. First of all, they concentrated on a systematic search for manuscripts and texts in remote (especially monastic) libraries and on attempting to acquire new copies of old texts and/or to let them circulate among friends and fellow scholars. The most famous scholars engaging in such practices were Francesco Petrarca, Coluccio Salutati, and - above all - Poggio Bracciolini, who contributed to the rediscovery of Pliny 
the Younger, Cicero's Epistolae, and Lucretius (Sabbadini 1967). Second, they set upon tirelessly copying these texts and presenting them in a more appealing and comprehensible form, which led to the adoption of a new script, the humanistic script. They also undertook an in-depth examination of the preserved texts and a careful correction of them, as for instance in Ermolao Barbaro's Castigationes Plinianae or Angelo Poliziano's Miscellanea (Barbaro 1973-1979; Poliziano 1567), especially according to classical rules. Finally, after the invention of the printing press and the rise of the large printing enterprises, humanist scholars also acted as editors, correctors, and supervisors of the publication of printed editions. In this context, we may recall the cooperation of Marco Musuro, Andrea Navagero, or Giorgio Valla with Aldus Manutius, a printer with a strong classical background who endeavoured to print both graphically innovative and philologically correct editions (Reynolds and Wilson 2013, 123-164; Nuvoloni 2016, 80-86), or that of Erasmus of Rotterdam and Beatus Rhenanus with Froben's publishing house in Basle (Grafton 2011).

Despite all of these efforts, we cannot fail to note that the editorial work performed by humanists and the philological methodology employed by them at best consisted of (i) choosing the oldest and/or most authoritative manuscript (or group of manuscripts), and (ii) scattered or extensive corrections ope ingenii, mostly motivated by respect for the grammatical and syntactic rules of classical Latin (Timpanaro 2004, 15-27). Such an approach risked, for both classical and mediaeval texts, a dangerous distortion of the content through corrections not supported by a thorough and systematic collation of the entire manuscript tradition, and a transformation of the form based on personal or contemporary linguistic tastes. All of this lies at the roots of the later scepticism with which printed editions were met in modern philology and ecdotics. The editorial practices in the time of transition between manuscript and print have to be identified so that a modern editor can deal with the improvement or deterioration of the transmitted texts to be expected when preparing a critical edition. Therefore, we should ask ourselves not only how a text travelled through the age of handwritten manuscripts into that of printed copies; we should also identify the changes it experienced during that time, the places printed editions have in the stemma (the genealogical tree of the whole transmission; see 4.1), and what value scholars have assigned, or should assign, to the variant readings witnessed by printed editions.

I have chosen to provide some case studies as concrete examples of the way in which philologists and editors of texts have dealt with printed texts in the recensio of the witnesses of a text's diffusion, the establishment of a stemma, and the reconstruction of the correct and, if possible, original text. Before presenting them, it may be useful to briefly summarise our knowledge and basis for the interpretation of printed texts today. First of all, our knowledge of the extension of printing between the second half of the fifteenth century, that is, in the decades after the invention of the printing press and the first publication of the Gutenberg Bible, and the end of the eighteenth century has consistently improved. New attempts to catalogue 
incunabula (i.e. prints from before AD 1501) and early modern prints have considerably increased our knowledge of the number of printed texts of a classical, patristic, or mediaeval work. Examples include the Gesamtkatalog der Wiegendrucke (gesamt katalogderwiegendrucke.de), the Incunabula Short Title Catalogue (data.cerl.org/ istc), the Italian EDIT-16 database (edit16.iccu.sbn.it), the Universal Short Title Catalogue (ustc.ac.uk), or the Medieval Evidence of Incunabula database (data.cerl.org/ mei/_search). Second, seminal research conducted, among others, by Andrew Pettegree, Lotte Hellinga, Anthony Grafton, and, more recently, Cristina Dondi and Angela Nuovo has shed more light on the history of the early modern printed book and the editorial and philological practices related to the preparation of a printed edition, its production, and its diffusion on the book market.

The way in which editors of classical, patristic, and mediaeval texts have dealt with prints cannot be called coherent. Depending upon (i) the number of manuscripts preserved, their quality, and their antiquity; (ii) the type and the quality of the printed texts, and their connection with one or more branches of the manuscript tradition; (iii) the connection between recent (read: fifteenth-century) manuscripts and first (read: incunabulum) printed editions; and (iv) the renown or obscurity of the learned scholar who edited the text, modern editors have made different choices: for example, when dealing with Beatus Rhenanus' editions, they have stressed the historical value of the edition in question but not necessarily the philological one. To my knowledge, there is neither a coherent approach nor a systematic discussion of the methodology to follow, one major exception being Alfredo Stussi's attention (and call for attention) to prints with special reference to vernacular or mediaeval "popular" texts, where the print is the last step in a long journey of a work from its origin to its first manuscript diffusion and later to its print reception (Stussi 2006, $37 \mathrm{ff} ., 88-95)$. More precisely, Stussi invites future editors of texts to look at both manuscripts and printed editions, since the latter may reproduce codices now lost or may offer better readings or interesting variant readings due to their particular history. This suggestion is undoubtedly important; but the editorial practice followed by editors is different and not homogeneous (on editions of printed texts, see 7.8). I will provide three examples of the state of the art - without any pretence of exhaustively dealing with the approaches - concerning a classical text (in this case, Lucretius), a patristic one (Tertullian), and a mediaeval one (Papias).

\subsubsection{Classical literature: Lucretius}

Lucretius' De rerum natura, edited, among others, by Martin (1963), by Ferguson Smith (1975), and by Ernout (1948-1955) can serve as an instructive example. Lucretius' editio princeps was published in Brescia in 1472/1473, edited by the humanist Tommaso Ferrando (on whom, see Baldacchini 1996; Beretta 2016). The long and well-studied textual tradition can be divided into two main eras, the Carolingian and the humanistic one. The tradition of Lucretius originates in a lost common an- 


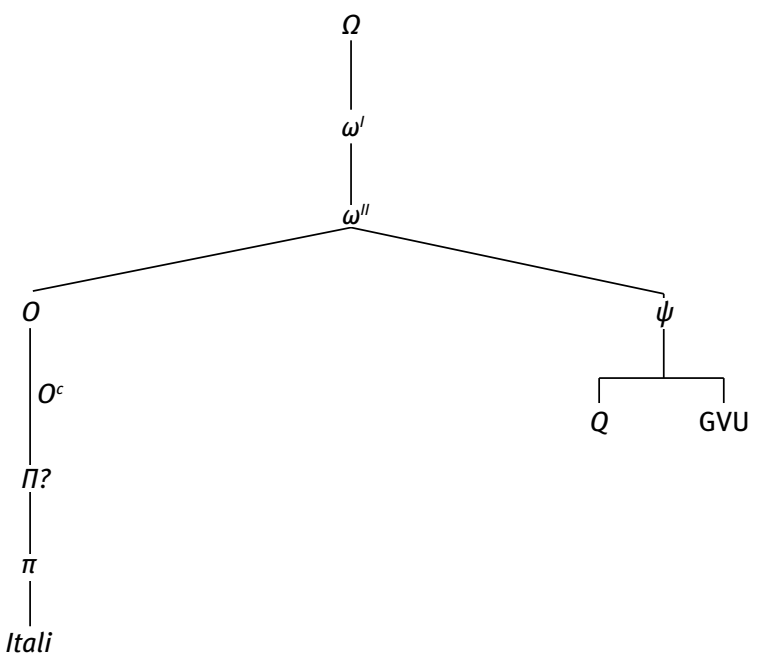

Fig. 1.4-1: Stemma of Lucretius' De rerum natura. Source: Reynolds (1983, 218).

cestor usually designated as $\omega^{I}$ and written, according to Karl Lachmann, in a preminuscule Caroline, whereas the pre-archetype $(\Omega)$ was produced in Gallia between the fourth and fifth centuries (Reynolds 1983; see also Butterfield 2013). This exemplar $\left(\omega^{I}\right)$ was affected by several accidents, causing mistakes in the sequence of the pages and errors in prosody in some verses. From its Carolingian copy, $\omega^{I I}$, which is the actual archetype (see 4.1.1) of all extant texts, the two main manuscript branches descend (see fig. 1.4-1), one represented by what is known as the Codex oblongus (O: Leiden, Universiteit Bibliotheek, Voss. Lat. F. 30), the other by the Codex quadratus (Q: Leiden, Universiteit Bibliotheek, Voss. Lat. Q. 94) and two fragmentary manuscripts, the Schedae Gottorpienses (G: København, Det kongelige Bibliotek, G. kgl. S. $2112^{\circ}$ ) and the Schedae Vindobonenses ( $V$ and $U$ : Wien, Österreichische Nationalbibliothek, 107, f. 1-6 and 7-10 respectively), all of which date back to Carolingian times. These codices sporadically resurfaced during the Middle Ages without giving the work any great renown or diffusion: Lucretius was rarely read during the Middle Ages. It was the discovery of an obscure, now-lost manuscript, ultimately derived from $O$ and commonly designated as $\pi$, in a "locus satis longinquus" (quoted in Clark 1899, 125) [a rather remote place] by Poggio Bracciolini in 1417 that gave Lucretius' poem new popularity among the learned. Poggio entrusted his own copy of this manuscript $(J)$ to Niccolò Niccoli and never received it back; it was subsequently lost. Niccoli's autograph copy is, however, preserved, and has been identified as the codex Firenze, Biblioteca Medicea Laurenziana, Plut. $35.30(L)$. From this copy, albeit with some indirect connections to Poggio's and Niccoli's manuscript copies, a new tradition originated, the "Itali": twenty-three copied manuscripts in all, which help both in reconstructing Poggio's lost manuscript and in correcting 
the mistakes made by Niccoli while preparing his own copy. It is from this branch of the manuscript tradition that the first printed versions stem.

In the context of Lucretius' reception, the role played by the printed versions appears to be twofold. On the one hand, scholars dealing with cultural history have stressed the role played by the return of Lucretius' poem to the cultural scene where the development of scientific and philosophical culture during the Renaissance is concerned, a development reflected, above all, by the use of Lucretius as a source for the discussion of specific questions. But active philological interaction, for example annotations written in the margins of editions, was also not uncommon (see Beretta 2016; Norbrook, Harrison, and Hardie 2016; Passannante 2011; Palmer 2014; A. Brown 2010). On the other hand, philologists aiming to produce a reliable critical edition considered the "Itali" group only in terms of its connection to the older Carolingian codices, in order to establish that connection and the group's position in the stemma codicum, where it is now located at the end of a branch ultimately starting with the Oblongus. Thus, they concentrated their attention on the reconstruction of the origins of the tradition, without taking into account the characteristics of its later historical development. In this context, early printed editions cannot possibly play a relevant role for reconstructive philologists, neither as a source for emendation of the text nor as a conveyor of variant readings worth recording.

This clash between the "historical" and the "philological" approach becomes evident if we look at the three above-mentioned critical editions published during the twentieth century, namely by Martin (1963) in the Bibliotheca Teubneriana, by Ferguson Smith (1975) in the Loeb Classical Library, and by Ernout (1948-1955) in Belles Lettres. Browsing these editions, we notice that all "late" elements of the tradition are generally neglected, and the early printed editions are not used in a consistent way or even considered apart from some passing mentions. In this selective approach, not even the whole tradition of the "Itali" group is employed in the preparation of the critical edition and/or mentioned in the critical apparatus. Martin, for example, only quotes the manuscripts $A, B, C, F, L$ from the "Itali" group, which he considers relevant to the reconstruction of Poggio's exemplar, and the lost manuscript $J$, and leaves aside the others. Besides, it is not easy to tell from the editors' methodologies what role the early printed editions played in the editions and apparatuses. For example, in the extensive commentary by Deufert (2017), variant readings from printed editions are mentioned, especially when they offer interesting conjectures produced ope ingenii and may be useful for an improvement of the text. Martin includes among his list of witnesses the editio princeps, the Aldina print from Venice (1500), and the Juntina print from Florence (1512), but I could not detect any relevant use or record of the readings featured in these printed versions in the critical apparatus, not even to show whether they feature Binde- or Trennfehler (see 4.3.1) that might connect them to early manuscripts and therefore elucidate their place in a stemma. The printed versions' existence is only acknowledged as a part of a large, multifarious group of later, indirect, and reception-related sour- 
ces; these include authors from late Antiquity using or imitating Lucretius' syntagms, the early prints, and a long list of scholars and philologists who witnessed the use of a different text, emended it, and/or produced critical editions, such as Bentley, Diels, or Lachmann. The role these sources play is very limited. Ferguson Smith only refers to the prints in his bibliography $(1975, \mathrm{lxv})$, but as a rule does not include them in the edition of the text. Perhaps he did not consider them relevant at all in an edition that aims to offer a reliable text rather than a large overview of variant readings, and where great attention was paid to the contribution of modern scholars to the improvement of the text. Even when he does occasionally include them, the result is hardly beneficial to the reader, for it lacks clarity and respect for the chronology of the scholarship. For instance, with reference to 1.306 (Ferguson Smith 1975, 26), he records that the variant reading "candenti" for "dispansae", witnessed by Nonius (as already pointed out by Martin), is a reading shared by Lindsay and adopted by “ed. Aldina, Pius, ed. Juntina, Pascal, Diels, Büchner”. He thus merges indirect reception, printed editions, and earlier scholarship in one brief note. The third editor, Ernout, declares already in the introduction to his edition (1948-1955, 1:xix-xx) that, while facing such a clear, homogeneous textual tradition shown by the ninth-century manuscripts, he did not intend either to record errors witnessed by a single manuscript (!) or to overload the critical apparatus with "variantes inutiles". Although Ernout does not elaborate what a variante inutile is for him, and therefore makes his opinion on the matter difficult to judge, his statement could possibly be read as an attempt to respect a supposed "majority principle" aimed at avoiding any unnecessary overloading of the critical apparatus with variant readings featured in a single manuscript and clearly recognisable as errors (on what is to be included in a critical apparatus, see 6.3.1 below). But, as he provides no clear definition of what he classifies as variante inutile, we may well suspect that among them there are variant readings that could be of some interest for reconstructing the historical development of the text and/or textual innovations shown by humanist manuscripts and prints. This is not the place to discuss the editor's decision, merely to point out its consequences with regard to the later manuscripts and the printed editions, which may be summarised as follows: variant readings from humanist manuscripts (in fact only a selection of them) are mentioned "que là où elles apportent au texte une correction qui paraît sûre” (Ernout 1948-1955, 1:xix) [only when they offer a correction that appears to be sure], while printed editions are not considered at all.

The printed editions' low reputation is reflected both by their absence from the stemmata provided in the critical editions I was able to consult and by their scarce representation in the critical apparatus, and it appears to have affected the approach to the editio princeps as well. As noted by Beretta in the introduction to the facsimile published in 2016 (Beretta 2016, 45-47), the editorial work carried out by Ferrando (i.e. the editor of the 1472/1473 edition) has largely been either ignored or despised due to the fact that he relied on one single manuscript only, and his edition 
is considered as mediocre tout court (e.g. by Munro, who edited Lucretius in 1864). This is surprising because of the presence in it of several correct readings, and of its possible proximity to Niccoli's copy (as hypothesised by Reeve 1980, 33), which would grant the edition a place for itself and a certain independence within the "Itali" group.

\subsubsection{Patristic literature}

In Lucretius' case, late codices are considered deteriores from a philological point of view (possibly because of the enormous weight of the Carolingian tradition), despite the fact that they are seen as a decisive step in the historical reconstruction of the reception of the text and its role in the culture of the Renaissance and its philosophical predilections. The reason for this is clear: we have humanist manuscripts and, above all, early printed editions to thank for their decisive contribution towards the rediscovery of Lucretius and his subsequent renewed fame, but the reconstruction of the text is supposed to rely on the Carolingian tradition, namely on the codices believed to be closest to the archetype.

If we now turn our attention to philological practices used when editing patristic literature, the situation differs to some extent. It took some time for scholarship to acknowledge that humanism and the Renaissance were not classical-oriented times tout court, but that there was an interest, and consequently a market, for patristic authors and their works as well. As noted by Cesare Vasoli (1997), humanist culture was not just interested in literature, philology, and culture, but developed a critical conscience and a considerable interest in morals and ethics, and consequently became aware of the contemporary moral decadence and of the necessity of a spiritual instruction that only the Christian patres could offer, both the Latin and the Greek Church Fathers, some of whom had recently been rediscovered and whose return to western Europe en masse during the second half of the fifteenth century resulted in a large manuscript tradition and, later, in a blooming of printed editions. All in all, we can state that a "patristic humanism" emerged between the fourteenth and fifteenth centuries, characterised by a constant interest in Latin and Greek Christian literature and, like “classical humanism”, by a certain fervour in discovering new texts as well as in examining and correcting them (overview in Gentile 1997).

The interest in patristic literature in the age of humanism has, at last, been thoroughly analysed during the past twenty years. Several anthologies have covered the philological and editorial practices devoted to the Fathers, the ways in which texts and authors were approached, studied, and edited (see, among others, Cortesi and Leonardi 2000; Cortesi 2002, 2004, 2006, 2010; Grane et al. 1993-1998; Colombi 2012; see also www-3.unipv.it/retrapa/). The mediaeval, humanist, and Renaissance transmission of the Latin and Greek Fathers has been thoroughly analysed with 
reference to selected examples, such as Jerome, Augustine, Tertullian, or Gregory of Nazianzus, as has the printed tradition of patristic texts. One volume has been devoted solely to editiones principes (Cortesi 2006). Finally, an anthology has been devoted to the transmission of patristic texts and the methodological issues it raises (Colombi 2012). At the centre of these studies, we find outstanding personalities, such as Ambrogio Traversari or Cardinal Bessarion, who played the same role for patristic literature as Petrarca, Salutati, or Poggio did for classical literature, as well as decisive historical circumstances, such as the Church councils that took place in Ferrara, Florence, and Constance. Editorial work performed by humanists in studying and editing patristic works, especially by leading figures such as Beatus Rhenanus or Erasmus of Rotterdam, has been taken into account as well. Finally, interest in editiones principes of patristic literature, both Latin and Greek, has strongly increased, in connection both with the history of print and the history of texts.

The reasons for this interest in editiones principes are numerous, but among them three stand out in importance. The first is the connection between the late branches of transmission of some works and the first printed editions, allowing philologists to identify, if not the exemplar used by the printers to prepare a print, then at least the branch of the manuscript tradition to which it belonged (HellingaQuerido 2014, 37-66, 67-101, 156-167), and therefore to connect handwritten and printed transmission closely. The possibility of finding such a connection is particularly frequent for Greek texts, whose reception in Latin Renaissance culture finds its beginning with the arrival in Italy of Greek manuscripts during the second half of the fifteenth century, and with their use for the production of the first printed editions. The second reason for the renewed interest in editiones principes can be found in the significance of the commercial, cultural, religious, and sometimes even political circumstances forming the context in which a printed edition (or several printed editions issued in the same place and/or over a specific period of time) was produced. Obviously, this holds true for all prints, but the emergence of printed patristic editions during a period characterised by the need for religious and spiritual reform, and/or by contrasts between the ecclesiastical hierarchy and that need for reform, certainly means that the assessment of their meaning has facets that other editions lack. If we look, for example, at the Basle or Paris prints issued during the sixteenth century, that is, during the attempts to reform the Catholic Church and adapt it to the spiritual needs of contemporary Christians, or at the short "Golden Age" of the enterprise of printing patristic texts in Rome (see Dondi et al. 2016), we see that the significance of these editions and their study cannot be related only to the technical and commercial features characterising the history of print, but should also be linked with the intellectual, political, and spiritual history of the time. On the other hand, if we look at Erasmus of Rotterdam's activity as editor of Jerome's works, he did not act as a neutral learned scholar; instead, he considers the spiritual message delivered by the pater ecclesiae and does not hesitate to criticise it when he sees that it manipulates the truth of Scripture (see Pabel 2002, 2008). Third, there 
is a certain historical continuity linking the editiones principes first to their early modern reprints (e.g. the Patrologia Latina and the Patrologia Graeca) and then to the nineteenth- and twentieth-century projects of editions ultimately aiming at replacing them and at putting at scholars' disposal the pillars of patristic literature in a philologically improved form (e.g. the CSEL or CCSL/CCCM series). Therefore, a historical overview of the patristic printed editions and their analysis from a historical perspective cannot be split into separate periods, but must be considered as a whole divided into mutually dependent sections. In general, the philological enterprise cannot be separated from or carried out in the absence of a full historical examination that includes both manuscripts and prints.

A case in point may be the reconstruction of the history of Tertullian's corpus of writings, which Pierre Petitmengin (2004) has masterfully traced in a special study, and which I will attempt to summarise here. Quintus Septimius Florens Tertullianus (ca. AD 160-after AD 220) was one of the most outstanding early Christian theologians and a ferocious anti-pagan polemicist. The high mediaeval (before AD 1200) knowledge of Tertullian's numerous writings was conveyed in four collections, the most famous and relevant of which is the one put together in Cluny and handed down by the famous manuscript Firenze, Biblioteca Nazionale Centrale, Conv. Soppr. J.VI.9, used by Kroymann (1906) for his edition. From the Cluny corpus, a new collection originated in three stages, the Hirsau corpus, which was ultimately the basis for the edition supervised by Beatus Rhenanus and published in Basle in 1521. Only two treatises retained a certain independence from this corpus: Adversus Iudaeos and Apologeticum. The latter enjoyed success in its own right in the entire Middle Ages. During the thirteenth century, a new collection was formed, witnessed by the manuscript Città del Vaticano, Biblioteca Apostolica Vaticana, Ottob. Lat. 25; at the same time, the Cluny corpus continued to be copied, albeit in different arrangements. A “changement dramatique” (Petitmengin 2004, 76) [dramatic change] took place in Italy, or more precisely in Florence, during the fifteenth century, when the Hirsau corpus was brought there and a new phase of the manuscript diffusion and a new branch of the stemma originated. This corpus can be considered as the basis for the humanist and Renaissance reception of Tertullian, since it was diffused not only in Italy (and read, among others, by illustrious readers such as Poliziano) but also in France. Finally, as we have already seen, the same Hirsau corpus, in two manuscripts, was used by Beatus Rhenanus for the edition published in Basle in 1521 (one of the manuscripts is now lost; the other is preserved in the successor to Beatus' library, Sélestat, Bibliothèque humaniste, MS 88). Beatus Rhenanus' edition, although not the first of Tertullian's works, is particularly important for scholars, not only because it witnesses a late branch of the Hirsau corpus but also because of interest in its editor, an outstanding personality in the history of philology, textual criticism, and editorial work, as well as in the religious and spiritual debates of his time.

In the case of Tertullian, we notice how it is possible to reconstruct a more or less uniform path leading from the handwritten tradition to the printed editions, 
and to put together a history of the texts and of the types of corpora and miscellanies handing them down. The same can be said, of course, for other Fathers whose textual traditions are relatively limited, and therefore easy to map and to deal with. For the study of Tertullian, however, we must emphasise that we are reliant on a Renaissance editor (Beatus Rhenanus) whose contribution cannot be overlooked, and indeed has not been. Of course, we are not always so lucky. Sometimes, as in case of Augustine's Confessiones, the printed editions (in this case, the one published in Strasbourg around 1470; cf. Gesamtkatalog der Wiegendrucke, A02893) represent the last step of a long textual journey, or better, the last witnesses of a long and extremely rich manuscript tradition that includes hundreds of copies (see Simonetti 2012). When facing difficult choices in establishing a selection of manuscripts as the basis for an edition, the editor may tend to neglect printed versions, especially when a wide manuscript basis is available, which is what has happened in the case of Augustine.

It is often difficult to assess the role played by the philologists who produced the early printed editions. These editors (a good example is Beatus Rhenanus himself) were not just philologists or scholars, but learned men involved in religious discussions and polemics, and, even when dealing with a manuscript or a group of manuscripts they considered reliable, they could not refrain from correcting the text more for ideological than philological reasons, as in the case of the "Roman-" or "Protestant-oriented" editions (see Grafton 2011; see also Petitmengin 2006 on the main characteristics of the editiones principes). Thus, printed editions may include conscious manipulations of the texts. Such manipulations may have a historical value, for they bear witness to the intellectual and spiritual struggle of the sixteenth century; but do they have to be taken into account during the preparation of a critical edition? Evidently, the case is different here from a simple correction ope ingenii in the edition of, for example, a classical text, as that is meant only to improve the quality of the text, whereas the manipulations in early printed editions may heavily influence or manipulate the content and the intellectual background of a text. In most cases, it would not be easy to document all of this because of the overabundance of material, and for this reason the evidence of the reception of the patristic texts in early prints has generally not been taken into account. It seems that editors of patristic texts, especially of works characterised by remarkable length and by the availability of several manuscripts, have tried to reduce the amount of sources by selecting the most correct and reliable ones among the oldest codices, simply leaving the further development of the text aside. In this further development, the printed editions represent the final step because of their generally close connection with the most recent codices at the time.

We can summarise the scholarly attitude towards early printed editions and their historical and philological importance as follows. The textual variation in early printed editions in the case of Lucretius' De rerum natura has been recorded but has not been taken into account in the establishment of the text itself (perhaps 
unjustly). This might also be the case with other classical texts whose transmission relies on several copies and runs through the Middle Ages. The situation is, of course, different, in cases where we have only a printed edition at our disposal, as in the case of Caelius Aurelianus' Tardae passiones, of which only the printed edition published in Paris in 1533 by Johannes Günther von Andernach, and no manuscripts (except for a brief fragment), is preserved. On the other hand, when looking at scholarship devoted to patristic texts, we notice a growing interest in printed editions from a historical perspective, but these witnesses are nonetheless left aside when dealing with the recensio codicum and the constitution of the original text. They are therefore not used or represented, either in the establishment of the text or in the constitution of the critical apparatus. A rare, but important, exception is Tertullian himself: Heinrich Hoppe, in his edition of Tertullian's Apologeticum published in Prague in 1939, does devote a special paragraph (Hoppe 1939, xxixxxxii) to the history of the printed editions and to the assessment of their value for the history of the text, tracing, for example, their inclusion in a specific branch of the tradition. Besides, in the case of the Apologeticum, a work that Rhenanus could not find in the manuscripts of the Hirsau corpus, Hoppe stresses Rhenanus' debt to the 1515 Aldina edition supervised by Iohannes Baptista Egnatius. Hoppe even incorporated their variant readings into the critical apparatus, especially - at least, this is my impression - when they turn against the vulgate version and bear witness to some alternative readings. The same positive attitude towards printed editions can be detected in cases in which philologists are forced to recognise the defective nature of the manuscript tradition. In these cases (e.g. Tertullian's De pudicitia), printed editions act as a necessary aid in establishing a better text (on this, see Micaeli 2014).

\subsubsection{Mediaeval literature: The specific features of the edition of Papias' Elementarium}

After dealing with examples derived from classical and patristic literature, it is now time to turn our attention to mediaeval Latin literature. The study of the transition from handwritten to printed form in the case of mediaeval Latin texts, and the assessment of the value that incunabula and sixteenth-century printed editions may have for accessing mediaeval Latin literature, is not highly developed, and is perhaps even tainted by some doubts and suspicions about the reliability of these sources. This somewhat negative attitude can be explained in terms of the following considerations. First of all, some works that we consider today to be excellent writings were never printed, whereas some minor, less original, compendium-like ones which had the function and the merit of being useful for spiritual and/or intellectual improvement found a market and a way into print. Works that were not printed and were left in manuscript form may afterwards have been lost (see Haye 2016, 191- 
204). Two good examples of such a contrast between what we today consider literary masterpieces that were not printed and everyday compendia that were, are (i) the scarce Fortleben of Ratherius of Verona's (887-974) Phrenesis, one of the finest introspective autobiographies of the Middle Ages, which has been preserved in only one manuscript and was never printed in early modern times, and (ii) the fine performance on the book market of Guido de Monte Rocherii's (d. 1331) Manipulus curatorum, a manual for priests that enjoyed more than twenty-one editions in German territories alone between 1474 and 1500 (Aquilon 2013). Therefore, the study of mediaeval Latin literature had to build up (and indeed did build up) its own canon of representative texts that is not always congruent with their diffusion.

Mediaeval Latin philology is ultimately based on the principles of classical philology and textual criticism, although several scholars have tried to grant the analysis of mediaeval texts and the editorial techniques devoted to them a certain methodological independence and specificity (Orlandi 2008; Göransson et al. 2016; P. Chiesa 2016). We cannot deal with those attempts here; for our purposes, we simply recall that some edition projects have been started with the aim of replacing old and flawed - early modern prints. Among these initiatives, the ongoing project of a critical edition of Albert the Great's Opera omnia, the Editio Coloniensis, can be mentioned; it has engaged the scholars of the Albertus Magnus Institute (albertusmagnus-institut.de) for several decades and aims at replacing the old editions printed during the seventeenth century by Petrus Jammy (1644-1651) and during the nineteenth by Emile Borgnet (1890-1899).

Could it possibly be a consequence of this mistrust of old prints and/or of the necessity of creating a specific philological method for editing mediaeval Latin texts that a discussion of the value of incunabula and early modern printed editions cannot be found in the manuals of mediaeval Latin philology (P. Chiesa 2002, 2016; Timpanaro 2004; Berté and Petoletti 2017), whose goal is to present problems and solutions when dealing with the manuscript tradition of mediaeval Latin texts? It is also rare, if not impossible, to find discussions of printed editions in the context of surveys of manuscript traditions. To give a single example: Barbara Fleith (1991) and Giovanni Paolo Maggioni (1995) are the most expert specialists involved in the study of the wide and complex tradition of Jacobus de Voragine's Legenda aurea, a collection of saints' lives written in several stages during the second half of the thirteenth century that enjoyed immense success both in manuscript and in print. Both scholars have worked extensively on determining the stemma and the accumulation of various redactions and versions; Maggioni has also studied the manuscript tradition in depth to distinguish the author's versions and establish how they evolved, and to classify manuscripts in the branches of the stemma. Astonishingly, neither Fleith nor Maggioni devoted even a single paragraph to printed editions, as if they were a disposable late by-product of the manuscript tradition and not witnesses of the development of the texts! Perhaps they made this choice because the search for an "original” or "author's" version was easier to perform with the help 
of codices alone, or because the richness and complexity of that same manuscript tradition made it necessary to untangle the manuscripts in order to select the ones an edition could be based on (see P. Chiesa 2016, 99-103).

An interesting exception to this selective editorial practice adopted by mediaeval Latin specialists, which ultimately results in a disregard for printed editions which may be considered either too close to manuscripts, and consequently as belonging to the category of descripti, or not relevant in comparison with a large, rich, and complex manuscript tradition that becomes the ultimate "battlefield" of philological methodology - is represented by the critical edition of Papias' Elementarium initiated by the extensive work of Violetta de Angelis, whose published findings are still limited to a very small section of the work, namely the letter $A$ (de Angelis 1974). Papias' Elementarium, one of the most successful Latin dictionaries of the Middle Ages, was written between 1041 and 1063, possibly by a member of the clergy whose biography is obscure. The dictionary enjoyed huge success during the Middle Ages (the FAMA database lists 146 manuscripts; see fama.irht.cnrs.fr/en/ oeuvre/254652), and was printed in Milan in 1476 (printer: Domenico da Vespolate) and in Venice in 1485 (printer: Andrea de Bonetti), 1491 (printer: Teodoro de rogationibus de Aula), and 1496 (printer: Filippo Pinzi). Other editions followed afterwards, but de Angelis's attention was attracted by the presence in the three editions following the princeps (1485, 1491, and 1496) of several interpolations, omissions, and changes indicating a departure from the manuscript tradition. In her introduction (de Angelis 1974, xviii-xxi), she discusses the innovations shown by the first and the last of those prints, and explains them in terms of a contamination of the tradition and in terms of the work of the humanist in charge of the edition, Bonino Mombrizio (or Mombricius - see Spanò Martinelli 2001; de Angelis 2011). He concentrated his efforts mostly on the entries including Greek words, where he adds the correct Greek words after the usual Latin transliteration, and therefore introduces his own glosses. After this summary of the type of text and transmission de Angelis was confronted with, and having emphasised the attention she paid to the printed editions, which she did not simply dismiss as witnesses showing later interpolations, changes, and manipulations to be disparaged or left aside while longing for the purity of the "original text", it is now time to see how she made use of the readings and innovations provided by the two prints she mainly concentrated on (namely Milan, 1476, and Venice, 1496). Her method can be summarised as follows. Since she clearly acknowledges the impossibility of determining which family of manuscripts the original text rests on, and, on the other hand, which family already shows the interpolations that could lie behind the additions found in the prints, she adopts a threefold categorisation and treatment. All lemmata in the dictionary receive a number in the edition. Whereas interpolations shown by a whole family $\alpha$ and $\beta$ are simply inserted into the body of the text with a running number " $n$ " exactly like the entries represented in the entire manuscript tradition, the ones offered only by some codices are included in the main text but receive a number 
" $n$-bis". The same treatment and numbering as " $n$-bis" are reserved for the entries displayed by the prints that presuppose the contamination of the two families (in order to avoid confusion, she puts these in square brackets). Finally, the entries clearly interpolated by Mombricius are featured only in the critical apparatus (see de Angelis 1974, xlvi-xlix).

Clearly, the example provided by the critical edition of Papias' Elementarium cannot be considered the norm, for it represents a notable exception to the general lack of interest among philologists in prints and, above all, in their function as late witnesses of the dynamism of mediaeval Latin texts, especially as working tools or technical texts that could (and indeed do) show an internal instability per se, against which - or even adding to it - the humanist and Renaissance editors reacted or positioned themselves in their philological and editorial activity.

\subsection{Palaeography, codicology, and stemmatology}

Peter A. Stokes

As has been evident from the discussion so far, although there are printed books which are important or even central to textual transmission, the majority of texts which are addressed by stemmatology survive in manuscript books, and so the preparation of an edition will most often require working with manuscripts. This in turn means that an understanding of manuscripts as books and objects is essential for editors, and this in turn requires a good understanding of palaeography and codicology. At one level, this is obvious: editors need to be able to read the manuscript witnesses to their tradition, and this often requires familiarity with a relatively wide range of scripts and scribal practices. As well as simply reading the letters on the page, editors also need an understanding of abbreviations, likely scribal misreadings such as forms that may look like a certain letter in one script but a different letter in another script, and so on, as well as a broader understanding of the physical and cultural context of the text's transmission. This section will therefore commence with a brief historical introduction to the development and diffusion of the "auxiliary" disciplines; then, some examples of the significance of these to editing will be given; and finally the discussion will turn to some of the methodological implications of this section, particularly in today's digital context.

\subsubsection{Definitions and historical introduction}

In essence, palaeography means simply the study of "old” ( $\pi \alpha \lambda \alpha$ เó $)$ writing, whereas codicology refers to the study of the codex, the physical book and its structure. In practice, however, the details of these definitions and their scope have evolved considerably over the centuries. Palaeography has long been seen as an "auxiliary" 
discipline, the goals of which still include being able first to read historical scripts and then to be able to determine the date and place of writing and to identify samples of writing that were likely to have been written by the same person. While these remain a core part of modern palaeography, the field also incorporates, and indeed often focuses on, broader questions such as the development of scripts, the cultural influences that lead to changes in scribal practice, and work on society and culture more broadly, such as what changes in script can tell us about the exchange and interaction of ideas and cultures, and about questions such as learning and education, authority and its perception, and so on. The chronological range of palaeography's remit is not clearly defined, but the inclusion in it of the (European) Middle Ages seems clear; the study of Renaissance and perhaps early modern script - but usually no later - is typically considered part of palaeography as well. Nevertheless, palaeographers certainly have worked on more recent writing (e.g. M. Smith 2008), and the methodological overlaps between palaeography and modern forensic document analysis have also been noticed (on which, see esp. Davis 2007). The study of pre-mediaeval handwriting is sometimes distinguished as part of papyrology, although palaeographers certainly work with material written on papyrus and so the distinction here is far from clear-cut. Much the same can be said for writing in inscriptions, which can be formally classified as epigraphy but which clearly has overlaps with palaeography as well. Codicology, on the other hand, broadly refers to the study of the physical object rather than the text or writing in it; it therefore includes aspects such as the written support (usually paper or parchment) and its preparation, the ways in which pages are formed and bound together, the structures of bindings, and the ways in which these can be interrogated to determine how the book was used and changed over time. This interrogation of layers in the physical object to determine the history around it has often led the field to be described as an "archaeology of the book" (e.g. CNRS 1987). Both palaeography and codicology can also extend into other related topics such as the ways in which books were transmitted, used, and gathered into collections or libraries, the book trade, and many other topics which are now often labelled under the broader heading of "book history".

Although an awareness of and, to some extent, study of scripts and handwriting is evident during the Renaissance, if not earlier, the beginning of palaeography as a discipline is normally associated with works such as Jean Mabillon's De re diplomatica (1681, 2nd ed. 1709), a study which included discussion, characterisation, and reproduction of different Latin scripts, as well as Bernard de Montfaucon's Palaeographica Graeca (1708) and Humfrey Wanley's Librorum veterum septentrionalium catalogus (1705), in which Wanley attempted to systematically catalogue many hundreds of manuscripts and documents, using dated documents as comparanda for undated scripts. As Mabillon's title suggests, much of the work at this time was aimed at establishing the authenticity or otherwise of charters and other documents, an emphasis continued in other important works such as 
Scipione Maffei's Istoria diplomatica (1727) and the Nouveau traité de diplomatique by René Prosper Tassin and Charles François Toustain (1750-1765). Also significant during the Renaissance, but continuing at this time and indeed thereafter, was the search for and systematic cataloguing of manuscripts (a useful review of which has been produced by Touwaide 2010, 267-283; see also 1.4 above), often driven by the desire to find older and better exemplars of important texts. This emphasis on cataloguing and editing continued to develop throughout the eighteenth and nineteenth centuries, along with interest in the scripts and physical formats of manuscript books. Practices varied, particularly but by no means entirely according to country, with some institutions producing summary catalogues (such as those of the British, Bodleian, and Cambridge University Libraries) and others more detailed cataloguing. Similarly, some editors focused more than others on detailed studies of the known manuscripts in a given tradition: compare, for instance, the largely uncritical reprinting of older editions in the Greek and Latin Patrologiae of Jacques-Paul Migne with approximately contemporary works such as Emile Littré's edition of Hippocrates (1839-1861), in which he discusses how important it was for him to see and compare all the known manuscripts in libraries in Europe (Littré 1839-1861, 1:xviii-ix).

This emphasis on manuscript sources received further impetus in the later parts of the nineteenth century, in part connected to improved technologies such as photolithography that allowed cheaper and more accurate reproduction of images; a result of this was the increasing publication of albums and facsimiles such as those of the Palaeographical Society (E. M. Thompson, Warner, Kenyon, and Gilson 19031912; E. M. Thompson, Warner, Kenyon, Gilson, et al. 1913-1930). This increasing emphasis on scientific evidence can also be seen in developments such as the "New Palaeography", which was developed by students of Ludwig Traube such as Elias Avery Lowe and William Lindsay, both of whom worked to establish clear criteria for categorising and dating scripts, including a study with reproductions and descriptions of all known surviving literary manuscripts in Latin dating to before 800 (Lowe 1934-1971; see also Lindsay 1914 for further discussion of the "New Palaeography"). As well as making significant advances in method, the "New Palaeographers" (among others) served to increase the role of palaeography as a distinct discipline as opposed to a set of techniques and methods that formed part of diplomatics and textual criticism. Editors of texts also paid increasing attention to codicology, as demonstrated by works such as Jean Irigoin's Histoire du text de Pindare (1952). Indeed, both palaeography and the newly emerging discipline of codicology developed significantly during this time. Different approaches to, and indeed definitions of, palaeography continued to emerge, with some focusing more on the morphology or appearance of the script (Derolez 2003), some focusing more on writing as a dynamic process (such as Mallon 1952), and some looking more broadly at the social and cultural context of writing (an approach championed particularly by Armando Petrucci, among others); we might also mention the "integral" palaeogra- 
phy of Leonard Boyle (2001). The question of objectivity and clear criteria for dating, localising, and identifying hands continued to be discussed, and achieved prominence in a Latin context with work by Léon Gilissen (1977), who attempted to develop a purely quantitative method of scribal identification; although his work was not successful and was strongly criticised by his contemporaries, it is nevertheless still influential, particularly more recently with the application of computer vision and other related fields to this question. Another, much more nuanced attempt to find clear criteria for describing script is evident in the work of Collette Sirat, who worked principally on Hebrew palaeography and who drew on cognitive science and many other fields before finally concluding that no definitive, objective proof of scribal identification can be achieved (Sirat 2006, 310 and esp. 493). Indeed, the possibility or otherwise of using measurements and other quantitative methods in palaeography was the topic of fierce debate in the 1990s due largely to a series of articles that were published in Scrittura e Civiltà (Costamagna et al. 1995-1998). Technical developments also continued to be used here, such as the development of (relatively) accessible colour printing, which led to the publication of colour facsimiles from the 1970s. Codicology also progressed significantly in this period, with key works including those by Devreesse (1954), Gilissen (1977), Lemaire (1989), and Maniaci (2002); this list and substantial further bibliography has been given by Touwaide in his survey (2010, 307-309). Quantitative methods in codicology had considerably more success given that the material is much more suited to quantification and measurement, and also because the types of questions were different, focusing not on individual identification but rather on large-scale developments in book production, with perhaps the best-known work being Malachi Beit-Arié's SfarData database of mediaeval Hebrew manuscripts (sfardata.nli.org.il).

Moving into the present century, perhaps the biggest transformation in codicology and especially palaeography has been the advent of the so-called digital age, with near-universal access to personal computers among palaeographers, codicologists, and others working in related fields, along with increasing quantities of colour digital images of manuscript pages, catalogue descriptions, digital scholarly editions, and databases such as SfarData. Quantitative approaches to palaeography have taken on new life with the application of state-of-the-art techniques in machine vision and pattern recognition, and, at the time of writing, rapid progress is being made in the automatic treatment of handwritten text recognition, layout analysis, writer identification, and script classification (for one important discussion among many, see Kestemont, Christlein, and Stutzmann 2017). Access to images of manuscripts is also increasing enormously with the large-scale digitisation of entire repositories and with innovations such as the International Image Interoperability Framework (IIIF), meaning, on the one hand, that scholars now have images of handwriting of a scale and breadth that was never possible before, particularly for those based outside Europe, but also, on the other hand, that large-scale analyses of hundreds, thousands, or even millions of manuscripts, whether automatic, man- 
ual, or both, are now becoming feasible. Applications to codicology are less developed at this point, in part probably because existing technology is very advanced in the treatment of text and image but much less so for the intricate three-dimensional structures which form the basis of codicology, but nevertheless progress continues with codicological models, databases, and three-dimensional scanning and printing, including the increasing integration of codicological information into digital scholarly editions (a recent example being Stokes 2018b, esp. "Labs" > "Codicological Visualisation" and "Collation Visualisations"). As before, questions remain as to the nature of palaeography in particular and the degree to which these more "distant" approaches can or should respond to palaeographical questions, as well as where their limits might lie. Overall, however, quantitative and digital approaches are being increasingly accepted, as demonstrated by their presence in meetings such as those of the Comité international de paléographie latine; indeed, the view at the time of writing seems largely consistent with that expressed by J. Peter Gumbert some twenty years ago, namely that "palaeography and codicology are [...] happily [...] becoming also arts of measurement” (1998, 404; emphasis in original).

\subsubsection{The relevance of codicology and palaeography: Some examples}

Given this brief introduction to the background of palaeography and codicology, the question arises of how these relate to editing, textual criticism, and stemmatology. As has already been hinted, one aspect is the degree of overlap in some of the methodological and definitional debates in these "auxiliary" disciplines, including the question of being an "art" or a "science”, which clearly applies across them. As Tanselle has observed, "the search for properly 'scientific' method has been perhaps the dominant thread running through the history of textual criticism" (1994, 18-19), with descriptions of editing as "scientific" and therefore "objective" extending at least back to Lachmann, and with Maas and others seeking at least in part to systematise the editorial process as much as possible. The pervasiveness of this dichotomy extends much further than this, however: the relationship between the "arts" and the "sciences" more generally has long been a fraught one, and, as Lorraine Daston and Peter Galison (2007) make clear in their five-hundred-page history of the concept of objectivity, many people have been seeking a resolution to this problem across different disciplines for centuries in ways that are very much tied up with different intellectual and even historical moments. It comes as no surprise, then, that more recent developments in computing and the digital humanities have been applied in no small measure to editing as well as to palaeography, with automated methods developed particularly for collation and stemmatics, as indeed they have also been for attempts at transcription (through optical character recognition) and even layout analysis (for further discussion, see esp. Pierazzo 2015, 109-117). Such work has raised real questions about the nature of editing just as it has for palaeography, as well as about the collaborative nature of the editorial project. 
Furthermore, philology, and indeed most of the so-called "auxiliary sciences", deal to a greater or lesser extent with what can be claimed to be facts (if there is such a thing): a given text was written at some point, by someone, for instance. We may never know when, but there is presumably a "correct" answer in some sense, and it is very possible that the more technical sciences can help us find this "answer" in a way that is not at all possible with literature, for example, and perhaps even history (depending on one's point of view). However, the "answer" in this concrete sense is normally only a small part of what people in the humanities are typically interested in: knowing where and when something was written is normally the means, not the end. Furthermore, this notion of facts also has implications for editorial practice. It is sometimes argued that editors should distinguish between objective fact, "what is on the page", and editorial interpretation. A direct consequence of this is the idea of a library of digital texts which can be shared and used for different purposes since, if the "base" text is objective, then who (or what) transcribes it is irrelevant: by definition, the text will be the same, apart from any factual errors, and therefore it can be reused for any purpose (a discussion of such views is given in Pierazzo 2015, 92). However, as fig. 1.5-1 shows, context is essential in transcription: the only way we can resolve such ambiguities is by considering the linguistic context through the lens of our training and our understanding of the text. Simply deciding which letters are written on the page depends to a greater or lesser extent on the transcriber's understanding of the text and the physical object that carries it (Pierazzo 2015, esp. chap. 2).

\section{coc indecocur}

Fig. 1.5-1: St. Gallen, Stiftsbibliothek, Cod. Sang. 189, p. 76 line 5 (detail): Eucherii instructiones, Isidori liber differentiarum, S. Hieronymus super Daniel. Source: e-codices.ch/en/list/one/csg/ 0189. The example is taken from Pierazzo $(2015,87)$. The first image appears to read "ccc", but the context makes clear that the reading is in fact "ca". Image: CC-BY-NC.

In addition to these more theoretical considerations, examples also abound of very practical implications of palaeography and codicology for textual studies. One striking example of this among many, one which also illustrates problems in the subjectivity of transcription, emerged during the "LangScape" project, which ran at King's College London from 2006 to 2009 (langscape.ac.uk). One of the documents that was edited for this project was an English charter issued in 1061 which records the grant by King Edward of Ottery St Mary in Devon to St Mary's in Rouen (Sawyer 1968, no. 1033). The charter survives in seven manuscript copies, ranging in date from the thirteenth through to the seventeenth centuries. Like almost all charters from the period, the main text is in Latin, but a section, known as the "charter bounds", is normally written in Old English. However, a fourteenth-century enrolment of the charter is particularly unusual (London, National Archives, C 66/308 
(olim PRO 4 Ric II pt 1), m 3). In place of the Old English bounds is an unintelligible text, beginning "Arcest opstruet sente ont celen porco panon up ont celen [...]". The only way to understand this text is to think of it visually: to look at the letters as written in the cursive anglicana script of this fourteenth-century copy, and imagine which letters from the original eleventh-century script are closest in shape. Thus, eleventh-century $æ$ looks somewhat like anglicana ce, eleventh-century $g$ is close to round $s, f$ is closest to $p, d$ is similar to io, and so on. By making such comparisons, the project team was able to draw up a list of consistent misreadings, and, by more or less mechanically substituting these readings and adjusting the spacing where necessary, a very accurate Old English boundary clause emerged: “Ærest of stræt geate on tælen ford, panon up on tælen [...]” [first from the street gate to the ford of the [River] Tale, then up into the Tale [...]]. Although this case is in many ways extreme, it illustrates the degree to which palaeography can impact on textual editing, and indeed any editor will necessarily make judgements of likely copying errors based on the scripts of the witness, exemplar, and any potential copies in between.

Although the importance of palaeography to editing is relatively well known, that of codicology is perhaps less often stressed. However, understanding codicology and the physical structure of the book in question can again have a significant impact on editing. This is discussed in some detail by Andrist, Canart, and Maniaci (2013), who give a detailed breakdown of the different ways in which codices can be rearranged, and what the implications are of these for the production and transmission of the book and its texts. They explain this in terms of "units of production" and "units of circulation" (unités de production and unités de circulation), and the "discontinuities" (discontinuités) which one may observe. For instance, a manuscript may have a series of quires or gatherings which are constructed in the same way, with the same type of parchment, the same number of lines per page, and so on, but the scribal hand might change at some point in the middle of a text and quire. In this case, the discontinuity in the scribe falls in the middle of units of production for the material, and so one can be certain that the second scribe was aware of the first scribe's work, and indeed it is likely that the first and second scribe were working together, probably from the same exemplar. In contrast, if the change of scribes coincides with the start of a new quire, with different rulings, parchment, and so on, then this coincidence of discontinuities suggests that the scribes were not working together, perhaps were entirely unaware of each other, and were likely working from different exemplars. These two cases have clear implications for editorial practice, as they tell us very different things about the state of the text and its position(s) in a stemma.

Concrete examples of this are numerous (for several, see Andrist, Canart, and Maniaci 2013, chap. 4), but one example of both palaeography and codicology impacting our understanding of a text is The Vision of Leofric (the following discussion is a summary of Stokes 2011). This text as it survives was written in Old English and narrates a series of near-miraculous visions experienced by Leofric, earl of Mercia 
(d. 1057). Although brief and relatively little studied, this text has historical interest due to the person that it describes, as Leofric was one of the most important members of the lay nobility during the reign of Edward the Confessor (1042-1066; see further Baxter 2007). The Vision survives in only one known copy, which is written into a quire plus a bifolium added to the end of what is now Cambridge, Corpus Christi College, MS 367. Before the Vision in the quire is a Vita brevior of St Kenelm, namely a Latin text which gives an abbreviated life of a saint who was himself believed to have been Mercian royalty in the ninth century. Furthermore, the Vita brevior was copied by one of the few named scribes from Anglo-Saxon England, namely Hemming, who was a monk at Worcester (again in Mercia) and whose hand is found in several manuscripts, including Hemming's Cartulary, which is in turn an important historical document written at Worcester around the year 1096. The Vision falls between this text and a copy of a letter to the prior, cantor, and monks of Worcester, details which seem to place beyond reasonable doubt that this copy of the Vision was made at Worcester at the end of the eleventh century. This is a significant detail given that Leofric's sons, Edwin and Morcar, fared poorly after the Norman Conquest of 1066. However, the date and place of copying are not obvious from the text - indeed, the text itself suggests composition at Coventry - but its position codicologically in the same unit as the Vita brevior and the letter to Worcester makes its copying at Worcester almost certain. Furthermore, it is striking that the Visio and other texts survive in what is now a codicologically distinct unit comprising two quires, and we also have a slightly later Latin text which recounts that the bishop of Worcester had miracles associated with Leofric written down on a schedula. That the surviving text is that of the original schedula is probably stretching credulity too far, but it might suggest that the Visio was transmitted in such booklets, and so perhaps what we have now may always have been a single unit and perhaps never part of a larger manuscript.

A further and very prominent example of the importance of palaeography and codicology to textual studies is the second part of London, British Library, Cotton Vitellius A.xv, which among other things contains the only surviving copies of two important Old English poems, namely Judith and Beowulf, as well as three prose texts, again in Old English, known as The Life of St Christopher, The Wonders of the East, and Alexander's Letter to Aristotle. The received view of this part of the manuscript, often referred to as the Nowell Codex, is that it was written by two scribes in a single stage, both of whom were copying existing texts. However, Kevin Kiernan (1996, 120-139) has argued that the section of the manuscript containing Beowulf is codicologically distinct from those of the other texts, and therefore that this copy of Beowulf once existed in a separate codex, presumably a distinct manuscript book in its own right. He has gone on to draw several conclusions from this. One is that all of the scholarship arguing for (and against) the literary coherence of texts in the Nowell Codex is misguided, since the texts were not together at the time of writing and probably remained separate until the early modern period (Kiernan 1996, 139- 
140). He has also argued that the section containing Beowulf was written not only at a different time but also "with a far different attitude on the part of the first scribe" than the prose texts, arguing in particular that the text of Beowulf was very carefully written and proofread (Kiernan 1996, $140 \mathrm{ff}$.). He has also used palaeographical and codicological evidence to argue that one folio of the manuscript was actively palimpsested and rewritten by the scribe. From these and other points, he has then argued that Beowulf in its current state is a product of the early eleventh century, rather than from several centuries earlier, and therefore (among other things) that editors should be much less invasive in their emendations of the text. These views have been extremely controversial, and different interpretations of the palaeography and codicology have also been proposed (e.g. Boyle 1981; Dumville 1988), but Kiernan's study has nevertheless demonstrated the importance of codicology and palaeography to textual studies and the way in which they can potentially overturn a century of editorial and text-critical practice.

\subsubsection{Methodological implications: Collaboration and interdisciplinarity}

In addition to the need to understand palaeography and codicology when editing texts, as demonstrated above, the discussion here has further methodological implications in editorial practice. One is the way in which palaeography in particular undermines the notion of a "factual" or "objective" transcription, or indeed the very idea that one possibly can record "everything that is on the page" (see 1.5.1 above; see also Pierazzo 2011). Furthermore, it seems clear from the discussion above that stemmatology and the other "auxiliary sciences" are fundamentally interdisciplinary, and this raises important methodological and practical implications. Although this has always been the case to some extent, it has also often been observed that digital methods have introduced a new degree of collaboration into humanities research in general, and probably into editing in particular. The traditional image here is of the "lone scholar", working hours, weeks, or years in solitude to produce the definitive edition of the text which then emerges as a printed volume. According to this model, the principal stages of the process are all conducted alone: the transcription, collation, and preparation of the critical text, and the preparation of the accompanying material such as the introduction, contextualisation, and so on (Pierazzo 2015). In contrast, newer digital approaches demand collaboration throughout: the editor's expertise, unsurprisingly, is typically in editing and not in software development, machine vision, deep learning, and so on. Instead, the editor must work closely with a team of experts all with different expertise: one or more analysts to help develop the software specifications and requirements; one or more developers to implement the software; and, potentially, experts in particular parts of the process such as machine vision, textual analysis, or even natural language processing or phylogeny (see 8.1). 
The first point to note about this is that the "traditional" view of the lone editor is limited and somewhat romanticised, erasing as it does the significant input from librarians and archivists, conservators, series editors, subeditors, typesetters, proofreaders, sales and marketing staff, distributors of the printed text, and so on, not to mention often research assistants or students, and many others (on which, see McGann 1991, among others). Indeed, one might even go so far as to argue that the change with the digital is not so much that the work is more collaborative, but that the collaborative nature of the work is now brought more forcefully into view. Nevertheless, collaboration in a digital context seems more continuous and more dependent, insofar as the editor of a digital edition is often unable even to begin work on the edition without some initial contributions from an analyst and potentially a software developer, whereas an editor in a print context can generally produce the typescript of an edition without other help. Beyond this, however, are the assumptions and questions that arise when working in digital form. The types of collaboration in a digital context require effective communication across people trained in very different disciplines, and indeed the computer itself requires very explicit statements of knowledge and information that have typically been implicit in the past. Thus, questions such as "what is text?", or even "what is a letter?", become critically important (Caton 2013; Sperberg-McQueen and Huitfeldt 2018; Stokes 2018a). Indeed, the Text Encoding Initiative (tei-c.org) provides not only methods for encoding texts but also, as an inescapable part of these methods, a theory (or perhaps set of theories) of what texts are, "a tool for better understanding of texts and their features” (Pierazzo 2015, 118, citing Renear 2004 and Cummings 2008).

The challenge of being explicit and communicating across fields is well recognised; those taking it up often risk "becoming merely disciples" to a field that they do not fully understand, or, conversely, failing to see the complexities in a discipline and therefore seeing it as overly simplistic (Beer 2006). These challenges have also lain behind much of the difficulty that has been encountered in the application of digital methods to manuscript studies more generally. For example, in a meeting held at the Schloss Dagstuhl - Leibniz-Zentrum für Informatik, a group largely comprising computer scientists and palaeographers established a series of key challenges and questions for the application of digital methods and tools to palaeography (Hassner et al. 2012). The challenges, roughly paraphrased, included:

- how to optimise collaboration between experts in all the different domains;

- how to ensure that humanities researchers remain in control of their research, whilst taking advantage of the possibilities of computerised approaches;

- how to facilitate sharing, not only of data and results, but also of the methodologies involved more generally;

- how to use the outreach potential offered by computerised technologies to enrich humanities knowledge;

- how to obtain contextual knowledge and meaning from systematic analysis;

- how to gain and maintain access to data; 
- how to maintain and support interdisciplinary approaches to research (in this context, but also more generally);

- how to avoid problems of communication and terminology; and

- related to all of this, the problem of the "black box" - namely a system (whether human expert or programmed computer) which takes input at one end and gives "answers" at the other, without allowing any understanding of what happens in between.

There is of course no simple solution to these challenges, but it can help in addressing them to consider the different roles that such interdisciplinary work can involve. Some of these are obvious: on the one hand the computer scientist, and on the other the philologist (or codicologist, or palaeographer), for instance. Here, there are some areas of overlap: both are in academic positions with similar (though different) requirements for progression, and so on. On the other hand, to a large extent, the principal interest of computer science is often in developing new methods and algorithms, and much less often in developing the robust, user-friendly software that is needed in the humanities, less in trying to understand what the algorithm or its results actually mean for the real-world questions. These questions, however, are precisely what typically interest those working in the humanities. Those in the humanities may therefore want or need to work with a software developer or engineer rather than an academic researcher. This is not to say that the developer does not need to have any interest in the material: as Choi and Pak (2006) and many others have noted, successful work across multiple disciplines requires all parties to be invested and interested, particularly given the very high salaries that such people can command in industry and which are normally beyond those in academic contexts. Another role that is relevant here is the analyst. This person may be the developer or one (or more) of the academic researchers, but another common possibility is a specialist analyst as a distinct role. This may well be someone with a higher degree in the humanities who has then acquired relatively advanced technical skills; the analyst is usually able to write software at a functional level but does not necessarily have any formal training in software development. Instead, the analyst acts as the "person in the middle" who understands both the humanities and computing elements and is able to translate from one to the other, who can model the domain in a way that the computer can analyse, can recognise and draw out the interest and potential on both sides, and so on. This person's interests are likely to include elements of both the developer and the academic. In short, the analyst may well be the person who brings the project from multidisciplinarity to interdisciplinarity, turning the work into a true collaboration rather than a simple and oneway application of digital methods to the benefit of humanities research. 